\title{
The coffee rust crises in Colombia and Central America (2008-2013): impacts, plausible causes and proposed solutions
}

\author{
Jacques Avelino • Marco Cristancho • Selena Georgiou • \\ Pablo Imbach • Lorena Aguilar • Gustavo Bornemann • \\ Peter Läderach • Francisco Anzueto • Allan J. Hruska • \\ Carmen Morales
}

Received: 8 October 2014 / Accepted: 23 February 2015 / Published online: 11 March 2015

(C) The Author(s) 2015. This article is published with open access at Springerlink.com

\begin{abstract}
Coffee rust is a leaf disease caused by the fungus, Hemileia vastatrix. Coffee rust epidemics, with intensities higher than previously observed, have affected a number of countries including: Colombia, from 2008 to 2011; Central America and Mexico, in 2012-13; and Peru and Ecuador in 2013. There are many contributing factors to the onset of these epidemics e.g. the state of the economy, crop management
\end{abstract}

\section{J. Avelino $(\triangle)$}

CIRAD, UPR Bioagresseurs analyse et maîtrise du risque,

F-34398 Montpellier, France

e-mail: jacques.avelino@cirad.fr

\section{Cristancho}

Plant Pathology Department, CENICAFE, National Coffee Research

Center, Chinchiná, Colombia

J. Avelino $\cdot$ S. Georgiou $\cdot$ P. Imbach

Department of Research and Development, CATIE, Turrialba, Costa Rica

\section{Aguilar}

FEWS NET, Regional Office for Latin America and the Caribbean, Guatemala, Guatemala

G. Bornemann · A. J. Hruska

FAO, Plant Production and Protection Division, Panama, Panama

\section{P. Läderach}

CIAT, Regional Office for Central America and the Caribbean,

Managua, Nicaragua

F. Anzueto

Research Department, ANACAFE, Guatemala, Guatemala

J. Avelino $\cdot$ C. Morales

IICA-PROMECAFE, Guatemala, Guatemala

M. Cristancho

Centro de Bioinformática y Biología Computacional-BIOS,

Manizales, Colombia decisions and the prevailing weather, and many resulting impacts e.g. on production, on farmers' and labourers' income and livelihood, and on food security. Production has been considerably reduced in Colombia (by $31 \%$ on average during the epidemic years compared with 2007) and Central America (by $16 \%$ in 2013 compared with $2011-12$ and by $10 \%$ in 2013-14 compared with 2012-13). These reductions have had direct impacts on the livelihoods of thousands of smallholders and harvesters. For these populations, particularly in Central America, coffee is often the only source of income used to buy food and supplies for the cultivation of basic grains. As a result, the coffee rust epidemic has had indirect impacts on food security. The main drivers of these epidemics are economic and meteorological. All the intense epidemics experienced during the last 37 years in Central America and Colombia were concurrent with low coffee profitability periods due to coffee price declines, as was the case in the 2012-13 Central American epidemic, or due to increases in input costs, as in the 2008-11 Colombian epidemics. Low profitability led to suboptimal coffee management, which resulted in increased plant vulnerability to pests and diseases. A common factor in the recent Colombian and Central American epidemics was a reduction in the diurnal thermal amplitude, with higher minimum/lower maximum temperatures $(+$ $0.1{ }^{\circ} \mathrm{C} /-0.5{ }^{\circ} \mathrm{C}$ on average during $2008-2011$ compared to a low coffee rust incidence period, 1991-1994, in Chinchiná, Colombia; $+0.9^{\circ} \mathrm{C} /-1.2^{\circ} \mathrm{C}$ on average in 2012 compared with prevailing climate, in 1224 farms from Guatemala). This likely decreased the latency period of the disease. These epidemics should be considered as a warning for the future, as they were enhanced by weather conditions consistent with climate change. Appropriate actions need to be taken in the near future to address this issue including: the development and establishment of resistant coffee cultivars; the creation of early warning systems; the design of crop management 
systems adapted to climate change and to pest and disease threats; and socio-economic solutions such as training and organisational strengthening.

Keywords Hemileia vastatrix · Coffea arabica · Crop losses . Food security $\cdot$ Coffee price $\cdot$ Crop management $\cdot$ Climate change $\cdot$ Smallholder $\cdot$ Mesoamerica

\section{Introduction}

Coffee rust is caused by the fungus Hemileia vastatrix, an obligate parasite that affects the living leaves of the genus Coffea. Among the cultivated species, C. arabica is the most severely attacked. The disease causes defoliation that, when acute, can lead to the death of branches and heavy crop losses (Fig. 1). The infectious form of $H$. vastatrix is the uredospore (Fig. 2). The first symptoms are small yellowish lesions that appear on the underside of leaves (Fig. 2b), where the fungus
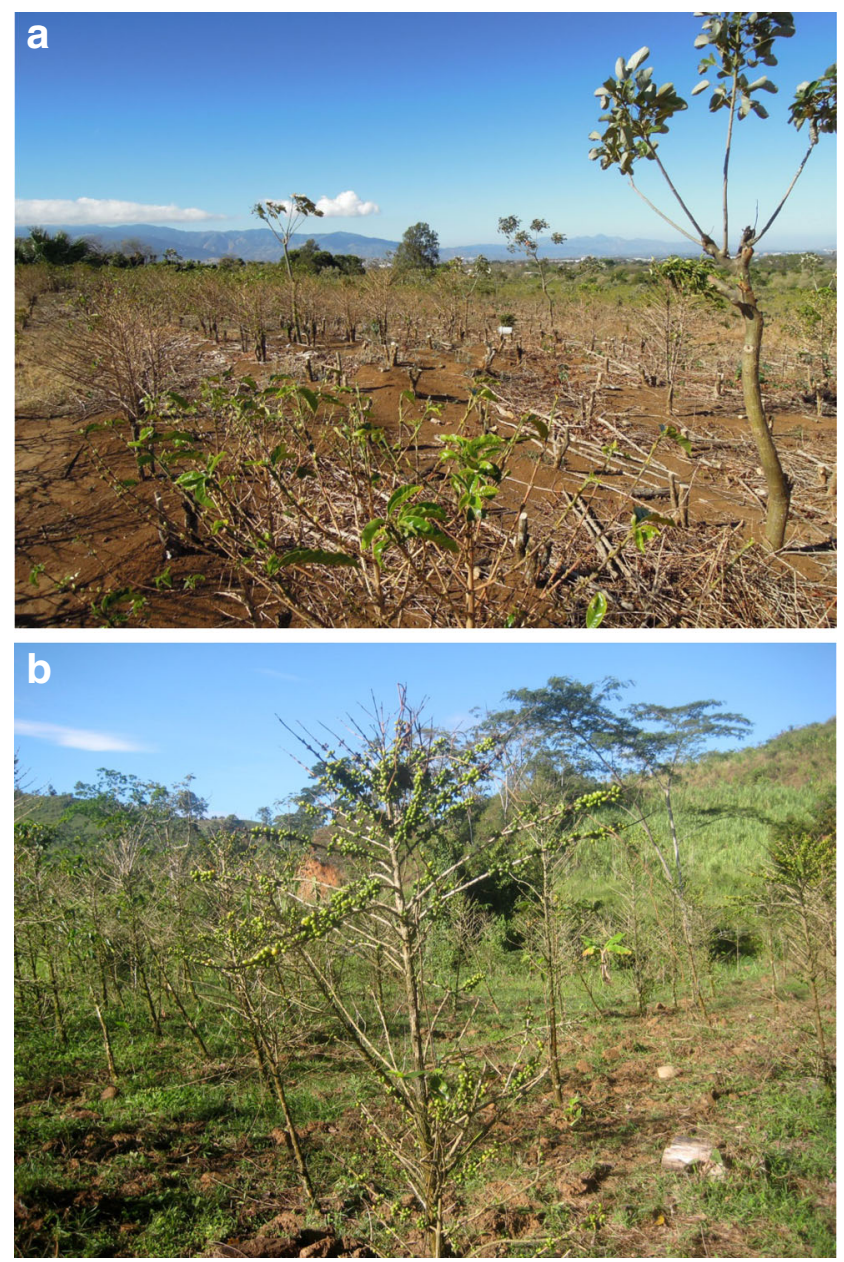

Fig. 1 Coffee plots severely impacted by coffee rust in Mesoamerica a in Heredia, Costa Rica, February 2013, 1000 masl b in Líbano, Tolima, Colombia, July 2011, 1720 masl; plants show symptoms of strong defoliation before harvest. a J. Avelino b M. Cristancho has penetrated through the stomata. These lesions then grow, coalesce and produce uredospores with their distinctive orange colour (Fig. 2a and c). Chlorotic spots can be observed on the upper surface of the leaves. During the last stage of the disease, lesions become necrotic.

Coffee rust became a concern for coffee-producing Latin American countries mainly before (Wellman 1952) and just after its introduction to these countries (Muller 1971; Waller 1972; Schuppener et al. 1977). At that time, the disease was feared, because all Latin American coffee plantations grew susceptible cultivars. However, soon after proving the effectiveness of chemical control and due to the relatively limited damage caused by the disease, particularly at high altitudes, Mesoamerican coffee farmers and technical authorities began to consider it to be manageable. This general view prevailed until the 2008 to 2013 epidemics hit Mesoamerica, from Colombia to Mexico, including Peru, Ecuador and some Caribbean countries (Cressey 2013).

Despite coffee rust not being feared by the farmers, the disease had caused significant losses even before the period 2008-2013. Most of these losses went unnoticed due to an interaction between the disease and the coffee tree phenology. For some (not well understood) reason, coffee rust attacks are more severe on high yielding coffee trees (Zambolim et al. 1992; de Carvalho et al. 1996; Avelino and Savary 2002; Avelino et al. 2006; Lopez-Bravo et al. 2012). In addition, coffee trees exhibit a biennial production rhythm, particularly at full sun exposure: high yielding trees normally produce low yields the following year and vice versa. After a high yield year, farmers therefore expect a low yield, with or without coffee rust. However, the reduction in production may not be attributed to the biennial production rhythm alone. Coffee rust may also contribute to this decrease by killing severely infected branches, such that they cannot bear fruits in the following year (Fig. 1). These secondary losses, i.e. losses caused by the current epidemic on productivity in the following years, have probably always existed. Primary losses, i.e. losses caused by the current epidemic during the current year's production, are less important. Usually, the fastest growth and the peak of the epidemic are during and at the end of the harvest, respectively (Avelino et al. 1991; Avelino and Savary 2002). Under these conditions, the current harvest is almost unaffected. However, under certain circumstances, the epidemic can reach high levels earlier in the season, causing the premature death of branches, and the loss of the fruits they bear, before the harvest. The recent epidemics, which affected Mesoamerica, resulted in unexpected high primary losses due to this phenomenon (Fig. 1). These apparent, direct, losses indicated that something unusual was occurring.

In this paper, we will first analyse the most intense epidemics that occurred from 1987 to 2003 in Mesoamerica, specifically in Central America and Colombia, in order to better understand the epidemics observed from 2008 to 
Fig. 2 Coffee rust symptoms and uredospores a sporulating orange lesions on a coffee branch with all the leaves infected $\mathbf{b}$ first symptoms of the infection with small yellowish lesions on the underside of a coffee leaf $\mathbf{c}$ detached uredospores with their characteristic orange color $\mathbf{d}$ characteristic echinulations of uredospores on a tape covered with vaseline $(\times 400)$; a to $\mathrm{c}$. Avelino, d courtesy of I. Merle
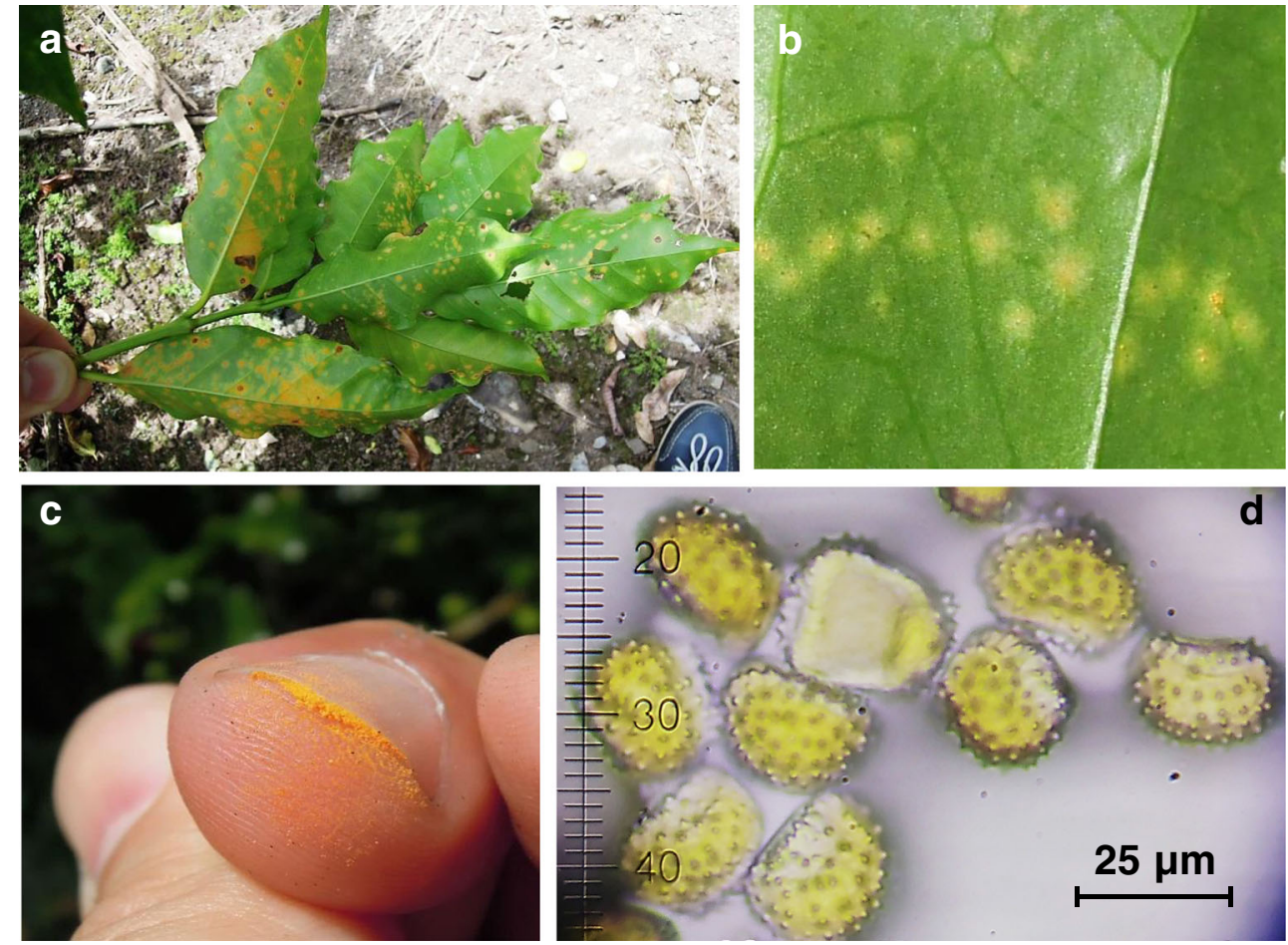

2013. We will then present the multiple impacts and plausible causes of the recent coffee rust crisis using available data from different countries. We will also describe the sources of variability of coffee rust attacks. Finally, we will propose some solutions for improved management of the disease in the future, in light of these recent epidemics and within the framework of climate change that is expected to strongly affect Mesoamerica in the near future (Hawkins and Sutton 2012).

\section{Severe coffee rust epidemics in Central America and Colombia from 1987 to 2003}

Before the period 2008-2013, several severe epidemics occurred in Mesoamerica at national level: Colombia, 1987-88 (information provided by CENICAFE, Centro Nacional de Investigaciones de Café, Colombia); Costa Rica, 1989-90; Nicaragua; 1995-96; and El Salvador: 2002-03 (Avelino et al. 1999; McCook 2009). These epidemics were driven by differing combinations of economic, agronomic, meteorological, and productivity factors (Table 1). All were concurrent with coffee price decreases. This is particularly noticeable in 1989-90, in relation to the end of the international agreement on coffee exports and the return to a free market; and in 200203 , at the height of the crisis of overproduction experienced in the 2000s, with the lowest coffee prices in history (Fig. 3). These low prices resulted in a reduction in coffee profitability, and thus reduced investment in coffee plantations (particularly in the use of fertilizers and pesticides), as coffee prices and the intensity of crop management are closely related (Taugourdeau et al. 2014). Consequently, coffee plots became particularly vulnerable to pests and diseases. However, although these economic crises were international, coffee rust only severely affected one country at a time, indicating that national factors also played a role, particularly production costs and the coffee prices paid to farmers, which are highly country dependent. Inefficient credit is another possible factor. For instance, the Nicaraguan epidemic has been attributed to the delayed release of funds with respect to the farmers needs for their agricultural operations, particularly with respect to pest and disease control (Vicegerencia Técnica de UNICAFE 1996). Additionally, this epidemic was associated with an earlier onset of the rainy season and, in particular, there was higher than usual precipitation in April (Fig. 4). This possibly promoted earlier development of the epidemic. An additional factor favouring the Nicaraguan epidemic was identified as being that around 20000 ha of new plantations, planted with susceptible cultivars, were bearing their first good harvest in 1995. These new plantations were the product of a coffee crop renovation and extension programme, launched in 1991. Due to the lagged positive relationship between fruit load and coffee rust attacks, it is likely that this increased production, combined with the possibility that the epidemic developed sooner and that fungicides were not applied in time, led to a severe epidemic in 1995-96, which affected only Nicaragua. Despite this severe epidemic, Nicaragua increased its production by $44 \%$ that year (http://www.ico.org/new_historical.asp). 
Table 1 Presumed factors related to coffee rust epidemics from 1987 to 2012 in Central America and Colombia

\begin{tabular}{llll}
\hline Factors & Country or region and period & Effects & \\
\hline Economic factors & Drop of coffee prices & Colombia, 1987-88; Costa Rica, 1989-90; & $\begin{array}{c}\text { Reduced coffee profitability } \\
\text { which led to suboptimal } \\
\text { management in coffee plots }\end{array}$ \\
& & Nicaragua, 1995-96; El Salvador, 2002-03; & Central America 2012-13 \\
& Inefficient credit & Nicaragua, 1995-96 & Direct favouring effects on \\
& Increase of fertilizer prices & Colombia, 2008-11 & epidemic \\
Meteorological factors & Increased annual rainfall & Colombia, 2008-11 & \\
& Sunshine duration reduction & Colombia, 2008-11 & \\
& Decreased daily thermal temperature & Colombia, 2008-11; Central America, 2012-13 & Increased coffee plant physiological \\
& Earlier rainy season & Nicaragua, 1995-96; Central America, 2012-13 & susceptibility \\
& Rainy season interspersed with & Nicaragua, 1995-96; Central America, 2012-13 & Nicaragua, 1995-96 \\
\hline Phenological factors & High production & & \\
& & & \\
\hline
\end{tabular}

\section{Impacts of the 2008-2013 coffee rust epidemics in Central America and Colombia}

Although every country has estimated the losses caused by coffee rust, during and after the epidemics, the estimates obtained are uncertain and difficult to compare between countries. This can be attributed to: (1) inaccurate assessments of the coffee rust intensity at country level (2) the different methods used for assessing coffee rust incidence in the region (3) the lack of harvest forecasts for some countries (4) a lack of understanding of the losses that coffee rust can cause in relation to the assessed attack intensities.

\section{Impacts on production}

The reduction in production during and after the years when epidemics occurred, compared with previous production, is not an exact reflection of the losses caused by the disease, due to the natural variation in production between years. However, reduction in production data is verified information that deserves to be examined. In Colombia, production decreased by $31 \%$ on average for the years 2008 to 2011 compared with 2007. In Central America overall, a $16 \%$ decrease in production was recorded for the 2012-13 harvest, the year of the epidemic, compared with 2011-12 (http://www.ico.org/new_ historical.asp). Two special cases are El Salvador and Costa Rica, which reported an increased harvest for $2012-13$ by $5 \%$ and $1 \%$, respectively. However, the production in El Salvador decreased by $54 \%$ in 2013-14 compared with 2012-13, mainly due to the impact of coffee rust (http://www. promecafe.org/). An additional $10 \%$ of the reduction in production, at the Central American level, was recorded for the 2013-14 harvest, compared with 2012-13 (http://www. promecafe.org/). Coffee plots strongly affected by the
Fig. 3 Coffee prices from June 1984 to July 2014. Straight lines indicate coffee rust epidemics in Mesoamerica. Central American Arabicas belong to Other mild Arabicas category. The composite indicator price is a weighted mean of the prices of Colombian milds, Other milds, Natural Brazilians and Robustas. Data from ICO (http://www.ico.org/new historical.asp)

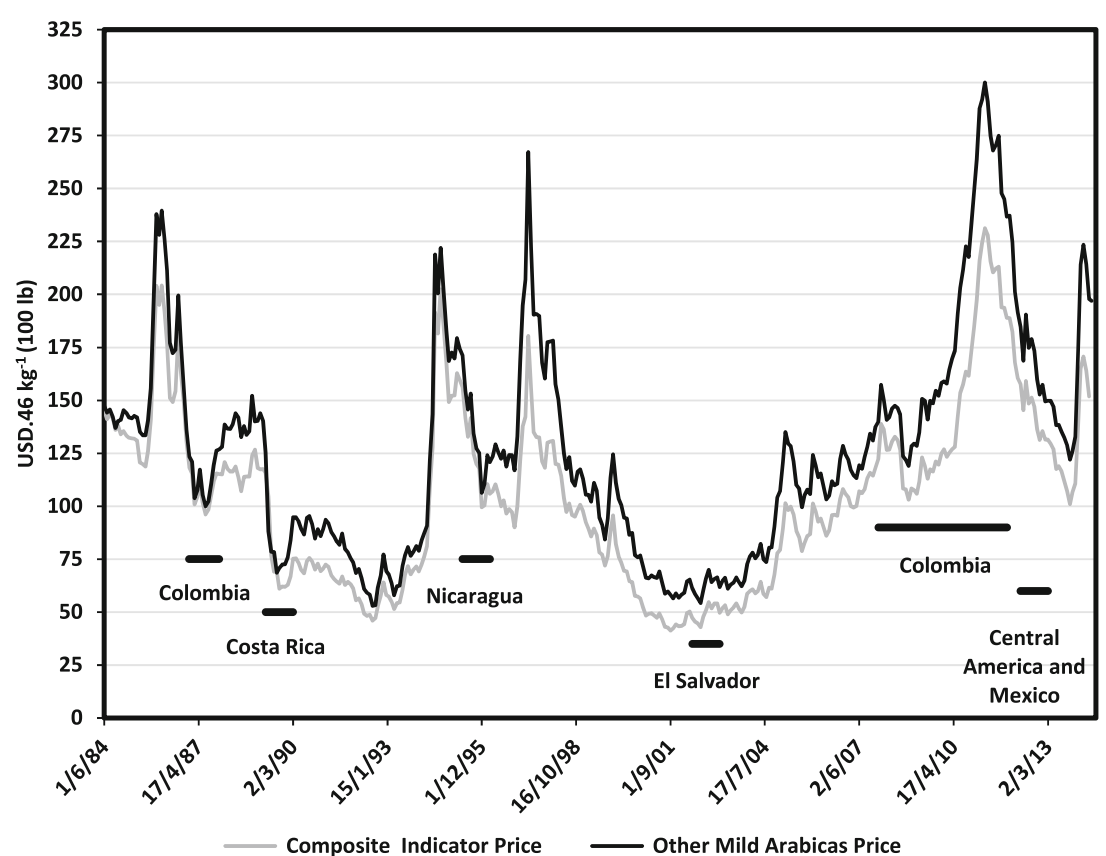




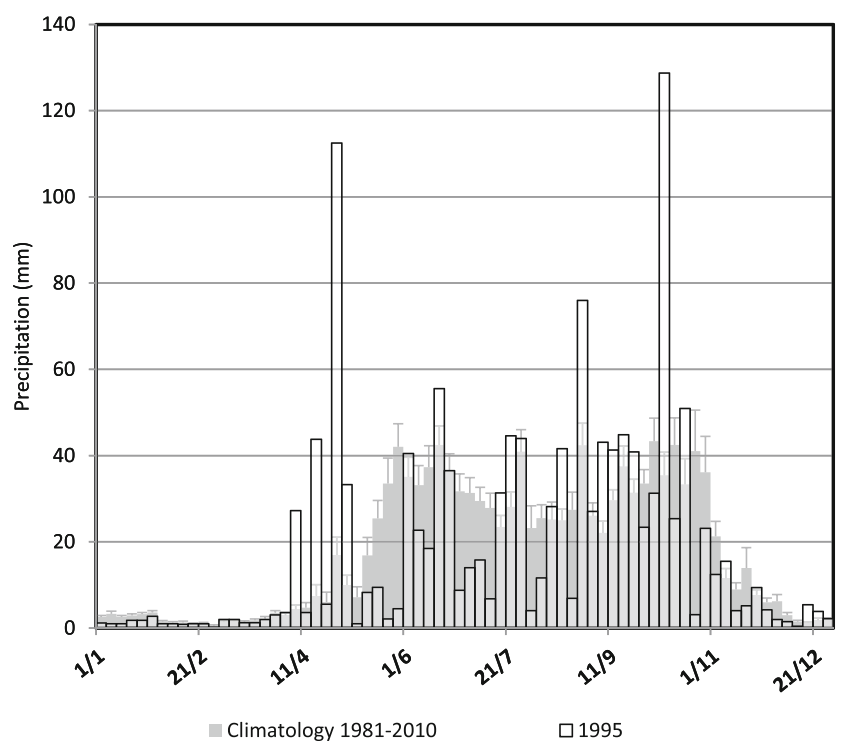

Fig. 4 Five day rainfall pattern in 1995 compared with the climatological average (standard error is indicated), in Matagalpa coffee producing region, Nicaragua. Data are from the CHIRPS (Climate Hazards Group InfraRed Precipitation with Station data, Funk et al. 2014) dataset (ftp:// chg-ftpout.geog.ucsb.edu/pub/org/chg/products/CHIRPS-latest)

disease required stumping to renew the vegetative tissue and to stimulate production again. These coffee plots will only start to produce normally again from the 2015 to 2016 harvest, indicating that the 2012-13 epidemic had impacts lasting at least 3 years.

\section{Food security impacts}

The Colombian and Central American coffee rust epidemics had strong social impacts and led to food security issues, as a result of the high dependence on coffee by most of the coffee farmers and labourers. According to FEDECAFE (Federación Nacional de Cafeteros de Colombia), in Colombia, more than 500000 families grow and obtain their livelihoods from the coffee crop, and for more than 200 towns, coffee is the only source of revenue. In Central America, coffee is the livelihood of about 2053 000 people (data provided by PROMECAFE, Programa Cooperativo Regional para el Desarrollo Tecnológico y Modernización de la Caficultura). Coffee rust has had social and economic impacts on two groups in particular in Central America: migrant harvesters and smallholders who own less than 7 ha of land. A large proportion of this population is not self-sufficient for food and needs to buy it. In addition, few options for income generation are available. The coffee rust issue therefore had implications on people's ability to access food, directly affecting food security (FEWS NET et al. 2014; Ruiz García and Mendoza Tijerino 2014).

Every year, the highest demand for labour on coffee farms is from October to March, which is the harvesting period when $70 \%$ of the labourers are temporarily hired. Most labourers are subsistence producers of basic grains. Income generated from coffee picking is used to purchase supplies for the first agricultural cycle and to supplement the household diet when food shortages are suffered, usually from April to August (FEWS NET et al. 2014; Ruiz García and Mendoza Tijerino 2014). According to calculations by PROMECAFE, employment in Central America decreased by $16 \%$ in $2012-13$ and by $7 \%$ in $2013-14$ due to the coffee rust epidemic. In addition, during the 2013-14 harvest, the World Food Programme in Honduras and Guatemala, and Action Against Hunger in Nicaragua reported a 13 to $27 \%$ reduction in coffee wages (FEWS NET et al. 2014). Unfortunately, coffee harvesters cannot increase their basic grain yield, due to the precarious conditions of their crops, making it difficult for them to compensate for wage reductions and meet their food needs. Additionally, these coffee labourers come from areas that have been hit by drought conditions over the past 2 years, and which are now experiencing food stress as a result of the reduced production of basic grains.

In addition to the reduction in production, the international price of other mild Arabicas fell sharply by $55 \%$ between September 2011 and December 2013, from 274 to 126 USD per $46 \mathrm{~kg}(100 \mathrm{lb})$ of green coffee (Fig. 3), while production costs reached their highest level in the last decade, for instance: 139 USD per $46 \mathrm{~kg}$ of green coffee in 2012-13 in Costa Rica, a $109 \%$ increase on the previous 10 years; and 143 USD per $46 \mathrm{~kg}$ in 2011-12 in Guatemala, a $97 \%$ increase from 2002 to 2003 (ICO 2014). Therefore, coffee was not profitable when coffee rust impacted Central America in 2012. Smallholders did not even benefit from the recovery of international prices during 2014, as they sold their coffee immediately after harvest, mainly at the cherry stage. Currently, the smallholder's situation is worrisome, as many do not cultivate basic grain crops for subsistence and their livelihood depends solely on coffee.

Although a widespread food security crisis is not expected (FEWS NET et al. 2014), some vulnerable areas of the region currently suffer from food stress, particularly in the dry corridor of Central America (East of Guatemala and El Salvador) and the Western regions of Honduras and Guatemala. This situation may be exacerbated during 2014, due to the low coffee production expected in 2014-15 and the El Niño phenomenon, which is currently impacting basic grain crops.

\section{Context of the 2008-2013 coffee rust epidemics in Central America and Colombia}

Economic context

As with previous epidemics, the recent Mesoamerican coffee rust epidemics were concurrent with specific economic 
contexts, in particular, a decrease in coffee prices for Central America (Fig. 3, Table 1). Mesoamerican coffee is particularly vulnerable to decreases in coffee prices because production costs cannot be reduced. Mechanisation of harvesting, for example, which is possibly the easiest way to reduce costs, is impossible due to the rugged topography of the region. Coffee is therefore a labour-intensive and expensive crop in Mesoamerica. In contrast to Central America, the Colombian epidemics of 2008-11 were concurrent with a $55 \%$ increase in the coffee indicator price, from 122 to 189 USD per $46 \mathrm{~kg}$ of green coffee, between January 2008 and December 2011 (Fig. 3). However, coffee farmers were hit by an increase in fertilizer costs due to an increase in international oil prices, which subsequently led to a reduction in fertilizer sales at country level (Cristancho et al. 2012).

Coffee is not macro-economically important for Central America. The contribution of coffee to the GDP (Gross Domestic Product) is no longer as important as it was 30 to 40 years ago when coffee was the most important source of trade for Central American countries (Segovia 2004). The coffee contribution to GDP has fallen below $10 \%$, with a maximum of $7.4 \%$ in Honduras, and less than $3 \%$ in Costa Rica, Guatemala and El Salvador (http://www.ico.org/profiles_e.asp? section $=$ Statistics).

\section{Meteorological context}

During the period 2008-2013, anomalies in several weather parameters (temperature, rainfall, and sunshine duration) were recorded in Central America and Colombia. Although the

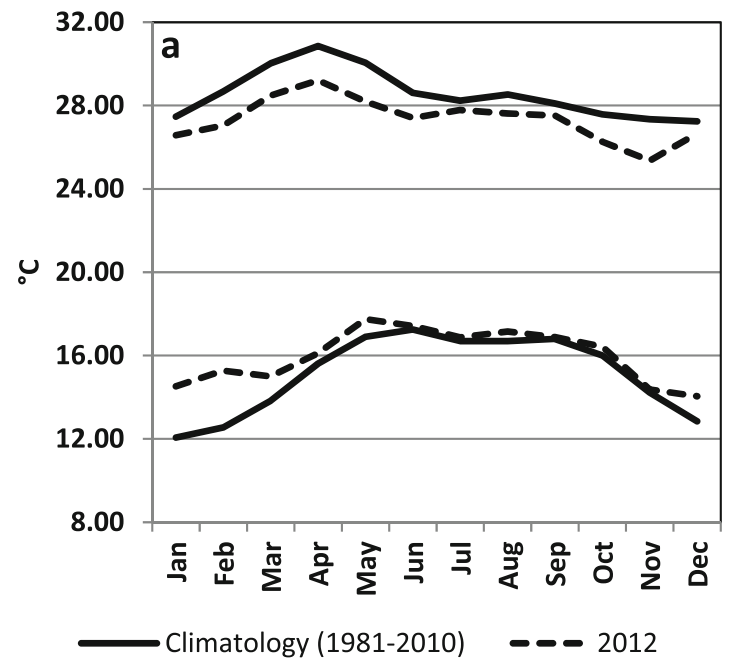

Fig. 5 Climatological data (1981-2010) compared with 2012 observed maximum, minimum daily temperatures (a) and thermal amplitudes (b). The temperature data were interpolated to determine the corresponding daily data at 1224 farms located across Guatemala, between 400 and 1800 masl elevation. The method used to interpolate the observed station temperature data was a liner splines interpolation, taking into annual mean temperature for 2012 in the Central American region was close to the long-term (1981-2010) mean value, reduced diurnal variability of temperatures was observed, due to higher values of minimum and lower values of maximum mean daily temperatures according to weather station data across the region. This is shown in Fig. 5 for Guatemalan coffee areas, where, in 2012, minimum daily temperatures increased by $0.9^{\circ} \mathrm{C}$, whereas maximum daily temperatures decreased by $1.2^{\circ} \mathrm{C}$ on average. Anomalies were also reported for the 2012 wet season mean precipitation and variability, with lower rainfall amounts and higher variability (Amador et al. 2013; Fig. 6). However, seasonal analysis using the CHIRPS dataset (Funk et al. 2014) shows positive rainfall anomalies for April to June (second trimester, end of the dry season and start of the rains) and negative during July to September (third trimester and most of the rainy season) for Guatemala. Honduras, Nicaragua and the Costa Rican highlands showed some positive anomalies during the fourth trimester (October to December; Fig. 6). In addition, stronger than normal winds occurred in July, due to El Niño conditions during the second and third trimesters (Amador et al. 2013). In Colombia, La Niña conditions prevailed during the period 2008-2011. In Chinchiná, increased rainfall, decreased sunshine duration and a decreased diurnal temperature range (due to an increase/decrease in the minimum/maximum, respectively), were recorded for that period in comparison with the 1983 to 2011 climate (Fig. 7). Annual mean maximum temperature decreased by $0.5^{\circ} \mathrm{C}$ and annual mean minimum temperature increased by $0.1^{\circ} \mathrm{C}$ during the period 2008-2011, while maximum annual coffee rust incidence reached $53.7 \%$ on average (standard deviation $=6.6$ ), with respect to

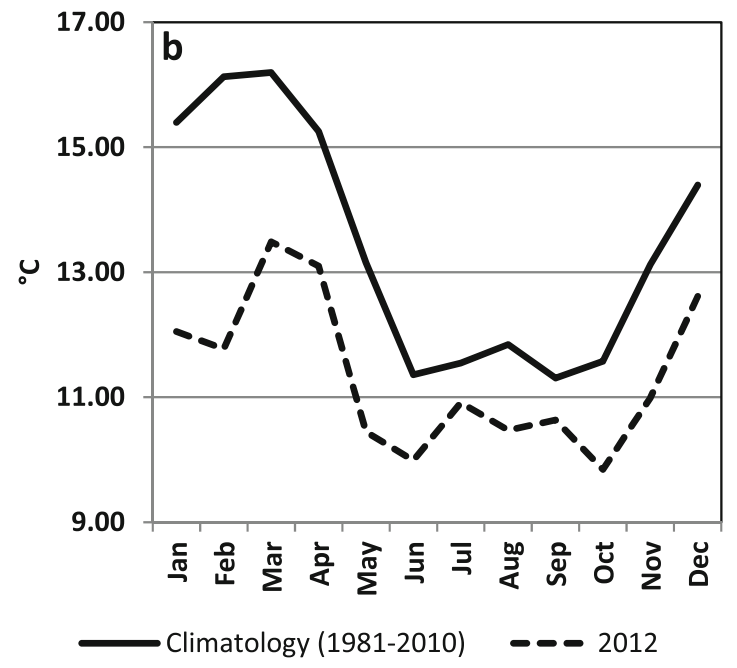

consideration the station and farm altitudes. These 1224 farms were assessed for coffee rust attacks in November 2012 by ANACAFE (see Figs. 9 and 10). Data averaged over each month, and over all 1224 farms. Daily temperature data available from 81 ANACAFE/INSIVUMEH weather stations located in Guatemala 
Fig. 6 Precipitation anomalies $(\mathrm{mm})$ in 2012 compared to the climate (1981-2010) for Central America. CHIRPS data (Climate Hazards Group InfraRed

Precipitation with Station data, Funk et al. 2014) from ftp://chgftpout.geog.ucsb.edu/pub/org/ chg/products/CHIRPS-latest. M: Mexico; G: Guatemala; ES: El Salvador; H: Honduras; N: Nicaragua; CR: Costa Rica; P: Panama; C: Colombia

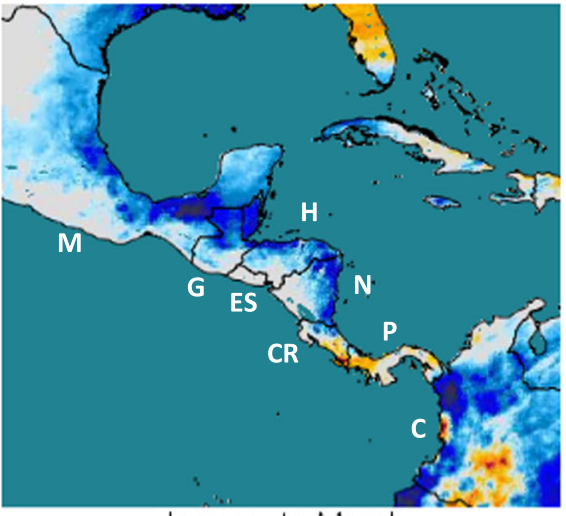

January to March

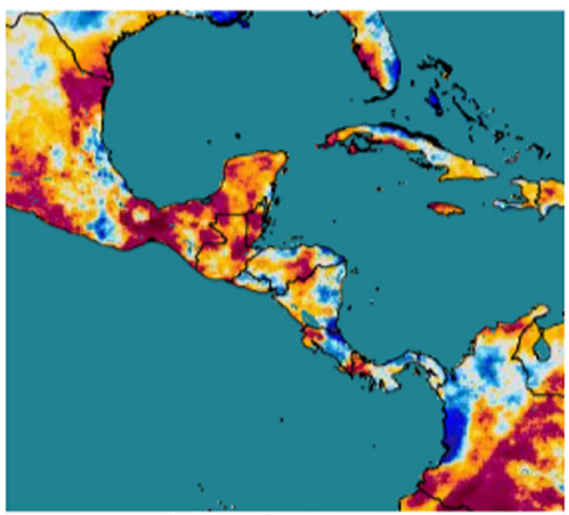

July to September

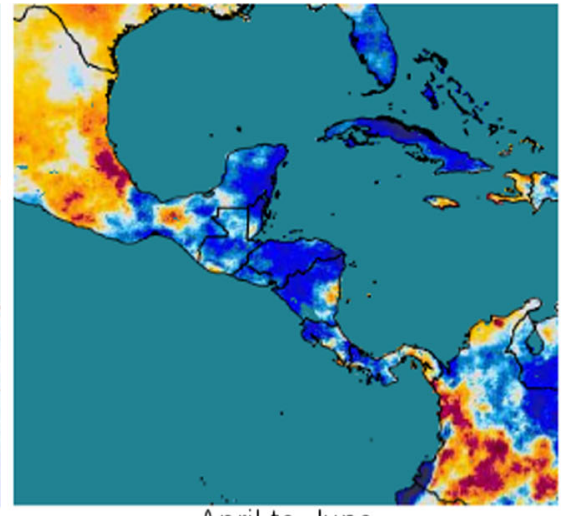

April to June

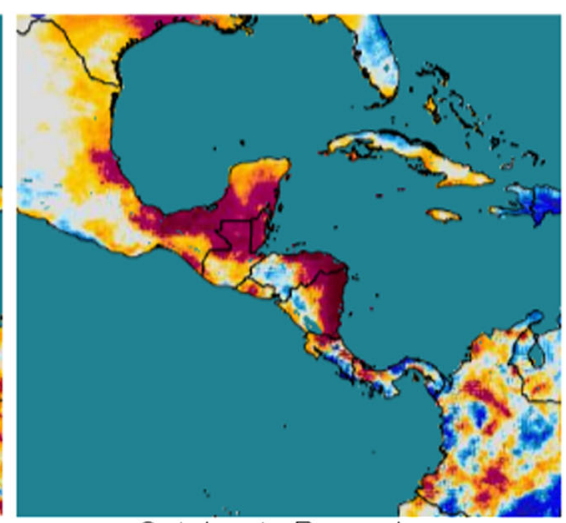

October to December
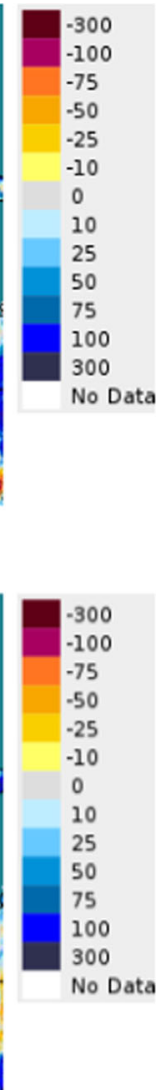

the 1991-1994 period, when very low coffee rust incidence was observed (maximum annual coffee rust incidence $=5.8 \%$, standard deviation $=0.8$ ). As a consequence, $78 \%$ of the 2008-2011 daily maximum temperatures fell within the optimal range for the latency period of coffee rust $\left(22-28^{\circ} \mathrm{C}\right.$,
Waller 1982). In other periods with lower coffee rust incidence, this percentage was always lower, with two minima: $67.2 \%$ in 1991-1994, and 66.4\% in 1999-2007 (low incidence, maximum annual coffee rust incidence $=10.2 \%$, standard deviation $=2.1$ ).

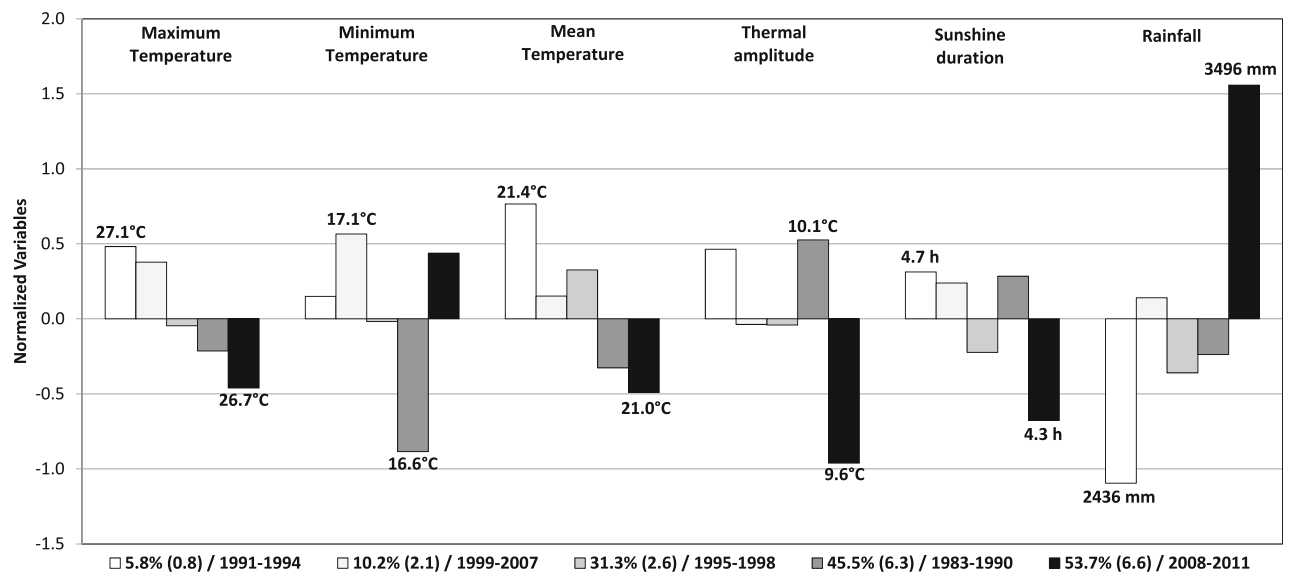

Fig. 7 Weather conditions during five periods with increasing coffee rust incidences in Chinchiná, Caldas, Colombia, 1430 masl elevation: mean of maximum annual incidence and standard deviation for each period are indicated in captions. Weather data were normalized to enable the presentation of all the variables in the same figure. The differences with mean for 1983-2011 (0) are represented. Mean values of non-normalized data are: $26.8^{\circ} \mathrm{C}$, maximum daily temperature; $16.9^{\circ} \mathrm{C}$, minimum daily temperature; $21.1^{\circ} \mathrm{C}$, mean daily temperature; $9.9^{\circ} \mathrm{C}$, diurnal thermal amplitude; $4.6 \mathrm{~h}$, daily sunshine duration; $2927 \mathrm{~mm}$, annual rainfall. Maximum and minimum mean values for each variable are indicated next to the bars. The five periods are significantly different for all the variables according to Kruskal-Wallis test $(P<0.05)$. Data are from CENI CAFE weather station 


\section{Other factors}

According to data provided by coffee institutes and agriculture ministries, $80 \%$ of the coffee stands in Central America are planted with cultivars susceptible to coffee rust, despite resistant cultivars being available since the 1990s in this region. Cultivar replacement requires a large initial investment; no or very low yields for at least the first 2 years, and thus a greatly reduced income. Central American coffee farmers are mainly smallholders (78 \% with less than 7 ha, $94 \%$ in Honduras, according to the information provided by PROMECAFE), with very low economic resources, who produce coffee using very few inputs, and cannot afford such a reduction in income. In addition, Central American institutes did not promote the use of resistant cultivars due to the scepticism, often unfounded, of some representatives of the international coffee trade about the resulting beverage quality of these genotypes (Van der Vossen 2009).

Difficulty in renewing coffee plantations has led to a process of ageing stands in Central America, which constitutes an additional weakness. In Guatemala, $25 \%$ of the coffee area is $>25$ years old. In El Salvador, $51 \%$ is $>20$ years old and $42 \%$ in Panama and Honduras (data provided by national coffee institutes for Guatemala, El Salvador and Honduras and by the agriculture ministry for Panama).

\section{Plausible reasons for the 2008-2013 epidemics}

\section{Economic and meteorological factors}

Coffee rust epidemics were likely driven by structural factors, such as the susceptible and ageing Central American coffee plantations, and several one-off factors, such as meteorological anomalies, and specific economic conditions which have direct effects on management (Table 1). Coffee crop management was probably suboptimal during the epidemics that occurred between 2008 and 2013, due to the economic difficulties that farmers suffered during this period. However, in our opinion, meteorological anomalies were crucial to the epidemic's development. Rainfall conditions in Central America differed from those in Colombia during the coffee rust epidemics, indicating that total rainfall was possibly not the main weather driven factor of the epidemics. This has previously been reported in Honduras and Malawi (Phiri et al. 2001; Avelino et al. 2006). The rainfall distribution seems much more important in explaining coffee rust epidemics. As with the Nicaraguan epidemic of 1995-96, the rainy season started earlier than normal in 2012 in Central America, probably inducing the onset of an early coffee rust epidemic. In addition, the lack of rainfall in this region in the third and fourth trimesters of the year was not very limiting for coffee rust development. Mayne (1930) had already observed that heavy and continuous rains were not conducive to severe epidemics (possibly due to spore being washed from leaves) and that the growth rate of the epidemic was faster in rainy weather with bright intervals. Actually, coffee rust uredospores do not need rainfall to spread in the second semester, due to the harvesting process where hundreds of thousands of harvesters working in coffee plantations efficiently assist the spread of the disease (Becker and Kranz 1977). In addition, the wind provides an efficient means of dry spore dispersal (Becker and Kranz 1977), and in 2012 the wind speed was higher than usual at the beginning of the harvest. Reduction in rainfall is not a limiting factor for spore germination either. In tropical regions, leaf wetness is always high during the night and early in the morning, even on dry days because of dew (LopezBravo et al. 2012). Moreover, uredospore germination is promoted by the absence of light (Rayner 1961). Coffee rust therefore normally finds both the required light and leaf wetness conditions during the night and early in the morning. It is interesting to note that the 2008-2011 epidemics in Colombia were concurrent with a reduction in sunshine duration, which possibly favoured coffee rust germination. However, the main and consistent factor associated with the severe coffee rust epidemics in Colombia and Central America is the reduction in the diurnal temperature range. This reduction possibly led to an increased number of days when the temperature fell within or close to the optimal range for coffee rust development $\left(21-25{ }^{\circ} \mathrm{C}\right.$ for germination, $22-28{ }^{\circ} \mathrm{C}$ for the latency period, Waller 1982). As a result, the latency period of the disease was probably greatly shortened.

\section{Sources of variability in epidemic intensity}

Possibly the main factor affecting coffee rust is the fruit load, which accounts for $50 \%$ of the coffee rust variability between coffee plants at plot scale (Avelino and Savary 2002; Avelino et al. 2006). However, during the 2008-13 epidemics, this factor seemed to play a limited role. Unproductive young plants in the field, and even plants from nurseries, were severely affected (Fig. 8). Similarly, coffee rust spread did not seem to be very limited by altitude. In the past, it was accepted that coffee rust was not a problem above 1000-1100 $\mathrm{m}$ above sea level (masl) in Central America (Avelino et al. 1991; Avelino et al. 1999; Avelino and Savary 2002; Avelino et al. 2006), and above 1600 masl in Colombia (Rozo et al. 2012). During the recent Guatemalan epidemics, almost equivalent attack intensities were observed at all altitudes between 400 and 1400 masl (Fig. 9). Very high intensities were also observed at altitudes of 1800 masl in rare cases. Similarly, coffee located above 1600 masl was unusually affected by the epidemics experienced in Colombia (Fig. 1b). This situation is consistent with increased minimum temperatures, as mentioned above. Heterogeneous spatial distribution of coffee rust intensity was observed in Guatemala at country scale, mainly 


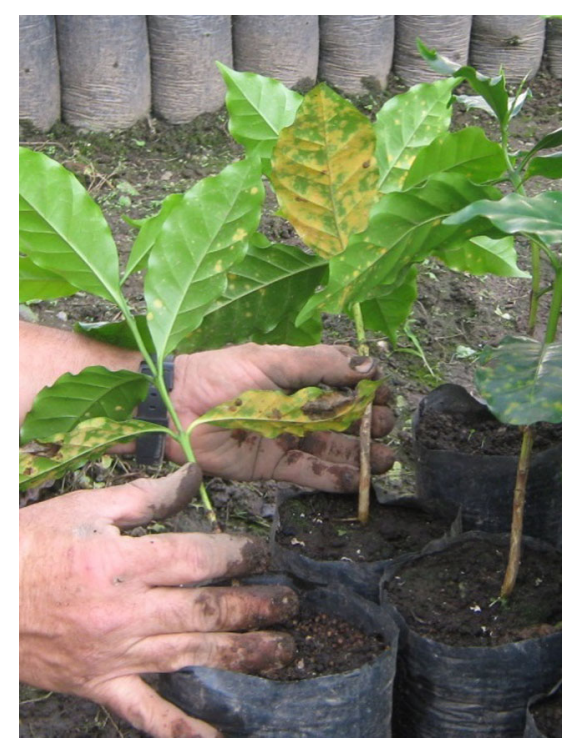

Fig. 8 Nursery coffee plants showing high incidence of the rust fungus in Chinchiná, Caldas, Colombia, 1310 masl, October 2010. Nursery plants had not been affected by the disease in previous epidemics in the country. M. Cristancho

due to this altitude effect, with very high altitude areas like Huehuetenango, in the North West, slightly affected by the disease, while others, like the South Coast (for instance San Marcos), at lower altitude, strongly impacted (Fig. 10). However, large variation in disease intensity was also seen within small areas indicating local effects, probably in relation to coffee management. A 2014 survey conducted in Nicaragua, in Jinotega and Matagalpa, two coffee areas strongly impacted by coffee rust in 2012, showed that farmers following a strict and systematic management program, including properly applied fertilizers and fungicides, had no serious trouble with the disease (Villarreyna, CATIE, personal communication). However, most of the Central American coffee farmers, who have reduced economic resources, normally cannot afford this kind of management, particularly during periods of low coffee prices. Inappropriate fungicide application is probably one of the main causes of the uncontrolled expansion of coffee rust. The key to successful coffee rust control is in applying fungicides preventively. This should be done as soon as $5 \%$ of leaves become infected (Rivillas Osorio et al. 2011), normally at the beginning of the rainy season (Avelino and Savary 2002). Fertilizer applications are also critical. Well fertilized plants have increased growth allowing them to renew leaves lost to coffee rust (Avelino et al. 2006), while avoiding death of the branches, thus preventing most of the primary and secondary losses. However, with the epidemics that started in 2008 in Colombia, fertilizer sales decreased due to increased cost, indicating that some of the coffee farms were inadequately fertilized (Cristancho et al. 2012). The old coffee trees of Central America, which have a low growth rate, are particularly exposed to extensive epidemics for this reason. Shade management also affects coffee rust. However, shade has many effects on coffee rust development, including antagonistic effects. The balance of these effects is therefore difficult to establish (Avelino et al. 2004; Avelino et al. 2006; LopezBravo et al. 2012). In Central America, equally high coffee rust intensities have been observed in both coffee plots under shade and at full sun exposure. However, the impacts, in terms of defoliation and dead branches, which are the main factors affecting yield, remain unclear. We believe that impacts should have been higher at full sun exposure, where coffee plants were particularly stressed (Fig. 1), due to the decrease of rainfall in 2012. The effect of shade on host defoliation due to rust probably deserves further investigation.

The question of new races

The issue of a new race, which could be the cause of the recent epidemics, has been explored in Colombia and Central

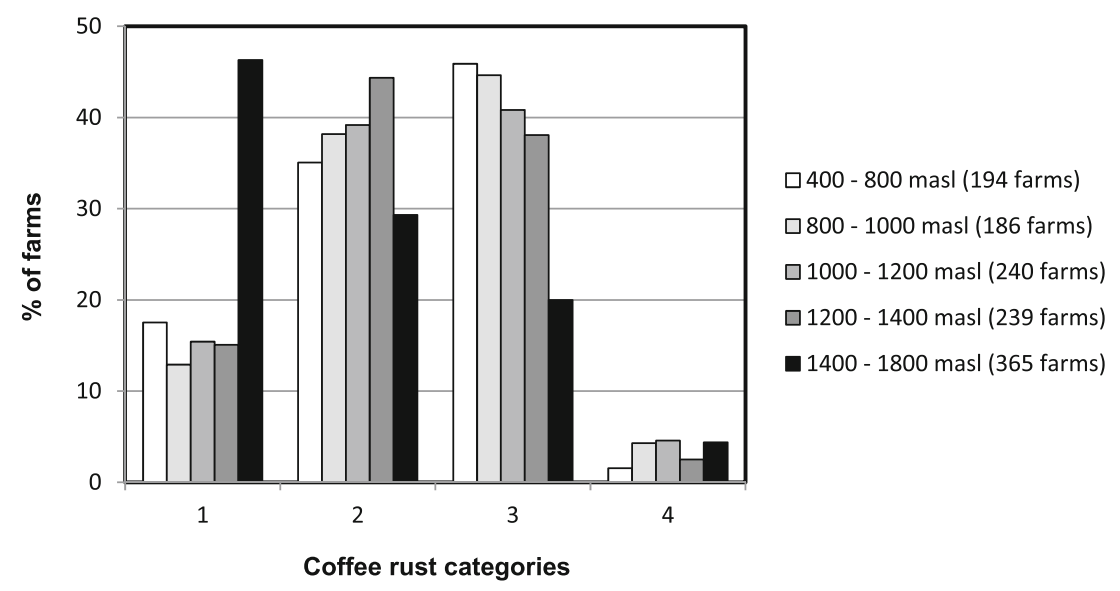

Fig. 9 Distribution of 1224 Guatemalan coffee farms, grouped in five altitude classes, according to the rust category they belong to. 1: no damage, 2: low damage (defoliation substantially below $50 \%$ ), 3 : moderate damage (defoliation around $50 \%$ ), 4: severe damage

(defoliation substantially above $50 \%$ ). Rust and altitude categories are dependent according to $\chi^{2}$ test, $\chi^{2}=153.5, P<0.0001, d f=12$. Data from November 2012 were provided by ANACAFE 
Fig. 10 Spatial distribution of the damage intensity caused by coffee rust in Guatemala, November 2012, and municipalities where first foci were detected in 2011. Meaning of damage categories: $\mathbf{1}$, no damage; 2, low damage (defoliation substantially below $50 \%), 3$, moderate damage (defoliation around $50 \%$ ); 4 , severe damage (defoliation substantially above $50 \%$ ). Data on 1224 farms in 2012 and information on first foci in 2011 were provided by ANACAFE

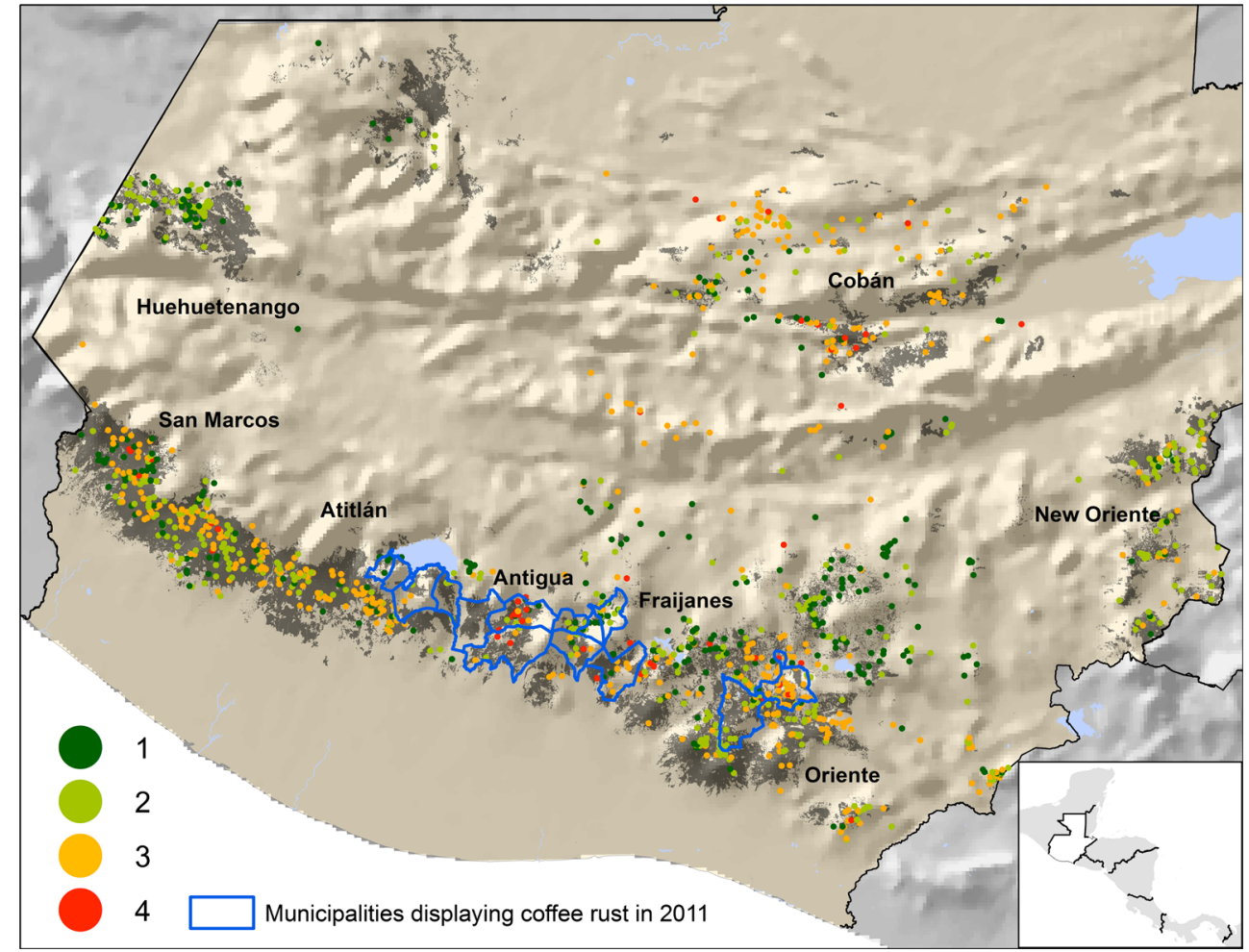

America. Since its introduction in Latin America in 1970, coffee rust has evolved as a result of the selection pressure exerted by resistant genotypes in collections or in commercial plots. Race II, which was introduced into Brazil and other Latin American countries possesses only one of the nine known virulence factors, $v_{5}$. Over time, races of increasing complexity, involving eight virulence factors in different combinations, have progressively appeared in Brazil (Sera et al. 2007; Cabral et al. 2009) and Colombia (Alvarado-Alvarado and Moreno-Ruiz 2005). Conversely, the evolution of coffee rust in Central America has apparently been slow. Until 1997, 21 years after its introduction to the region, only races II and I $\left(\mathrm{v}_{2}, \mathrm{v}_{5}\right)$ were identified (Avelino et al. 1999). This slow evolution may be explained by the near absence of selection pressure in the region. However, at the end of the 2012-13 epidemic, only races XXIV $\left(\mathrm{v}_{2}, \mathrm{v}_{4}, \mathrm{v}_{5}\right)$ and XXXVI $\left(\mathrm{v}_{2}, \mathrm{v}_{4}, \mathrm{v}_{5}\right.$, $\mathrm{v}_{8}$ ) were identified in Costa Rica, by ICAFE (Instituto del Café de Costa Rica) and CIFC (Centro de Investigação das Ferrugens do Cafeeiro), in genotypes susceptible to race II (circular $\mathrm{n}^{\circ} 2139$ dated 1st August 2013, distributed by ICAFE). Similarly, only races XXV $\left(\mathrm{v}_{2}, \mathrm{v}_{5}, \mathrm{v}_{6}\right)$ and XXVIII $\left(\mathrm{v}_{2}, \mathrm{v}_{4}, \mathrm{v}_{5}, \mathrm{v}_{6}\right)$ were identified in Guatemala by ANACAFE (Asociación Nacional del Café de Guatemala) and CIFC, from samples taken in July 2013 (information provided by ANAC AFE). The question of the role these races might have played in the 2012-13 epidemic then arose. One hypothesis is that they are not the cause of the epidemic but its consequence. A severe epidemic means a large pathogen population, many multiplication events, and therefore a larger number of mutation events and, consequently, a higher probability of having new races (McDonald and Linde 2002). In addition, these new races are not necessarily more aggressive than race II, as observed before with other complex races (Gil Fagioli et al. 1990). In Colombia, such behaviour was not observed. From 30 samples taken within the 2008 to 2011 period from commercial fields, 26 were assigned to race II. In addition, it was shown that the isolates causing the epidemics were not more aggressive than the pre-2008 isolates (Cristancho et al. 2012; Rozo et al. 2012). At this stage, it is therefore very uncertain whether the severe epidemics recently observed in Colombia, and in the whole Mesoamerican region, were linked to the emergence of new races and of more aggressive strains of the pathogen (Cristancho et al. 2012; Rozo et al. 2012).

The near continental scale evolution of several coffee rust epidemics

The coffee rust epidemics that have recently hit Mesoamerica, started in Colombia in 2008 where they lasted until 2011. In Central America, unusually high levels of coffee rust were detected in 2011-12, one year before the great epidemic, in specific localities of Southern and South-Eastern Guatemala (Fig. 10), as reported by ANACAFE, and in El Salvador in the Cordillera del Balsamo, according to information provided by PROCAFE (Fundación Salvadoreña del Café). Finally, Peru and Ecuador reported high incidences of the disease in 2013. 
The progress of coffee rust at this almost continental scale seems to follow the expected pattern for long distance dispersal diseases (Mundt et al. 2009), where epidemic velocity increases with distance from the initial source. This observation indicates that wind probably played a key role in coffee rust spread, although the disease is already present in all of the coffee growing countries and possibly in all of the susceptible coffee plots of Mesoamerica. Coincidentally, the meridional wind speed (North-South direction) in July 2012 was higher than at any previous time for that month (Amador et al. 2013). As a consequence, the appropriate conditions appear to have been present for long distance dispersal of coffee rust uredospores and the spread of the disease.

\section{Immediate responses}

Coffee rust epidemics have been met with a strong response from coffee and government authorities in Colombia. Since 2009 , over 300000 ha of the 600000 ha planted with susceptible cultivars have been replaced by the new resistant multiline variety, Castillo (Alvarado-Alvarado et al. 2005), such that Colombia now has more than $60 \%$ of its coffee fields planted with resistant varieties, enabling a significant reduction of coffee rust incidence to be achieved, from over $40 \%$ in 2009 to $3 \%$ in 2013 at country level (Federación Nacional de Cafeteros de Colombia 2013). Technical assistance to the farmers has been on hand to promote the benefits of the new multiline varieties and to demonstrate best agronomic practices to exploit their maximum potential. FEDECAFE and local governments have also implemented economic assistance for the renewal of plantations, which was of key importance for the successful and fast replacement of the susceptible coffee plantations.

New technologies and research projects have been undertaken to try to monitor the development of new races/isolates of the pathogen and improve the breeding program selection schemes (Rozo et al. 2012). Colombia has also put into practice a surveillance system to monitor the coffee rust incidence in commercial fields; more than 4500 plots all over the country are inspected four times a year. This routine monitoring allows early and fast detection of coffee farms with unusual increases in coffee rust, and alerts field technicians to promote control measures when necessary. The system also includes the evaluation of coffee berry borer (Hypothenemus hampei), the other major constraint of coffee growing in Colombia (Federación Nacional de Cafeteros de Colombia 2013).

Central America, as a region, responded very fast to the 2012-13 coffee rust epidemic with the elaboration of a regional integrated plan for fighting the disease. This plan is the result of a regional and international effort with the involvement of numerous organisations, private and public, under the coordination of PROMECAFE. This network, established in
1979 to face the introduction of coffee rust in Central America in 1976, provided a real advantage for implementing fast measures to fight the disease at regional level. The plan was ratified in March 2013 by the main regional political agriculture entity, the CAC (Consejo Agropecuario Centroamericano). The main actions of the agreed plan are: (i) production and distribution of existing coffee rust resistant materials (ii) renewal of old and susceptible coffee plantations (iii) launching of a new regional breeding program (iv) establishment of an early warning system (v) improvement of the coffee sector capacities by strengthening extension services and research. The plan was launched in 2013 to face the emergency. However, many of these actions will provide results in the medium to long term, acknowledging the reality that the coffee rust crisis revealed a number of weaknesses in the region, which require actions in the long term. Other activities implemented by the plan had an immediate impact on the attention given to vulnerable populations (smallholders and labourers). The World Food Programme (WFP), in 2013, concentrated its actions in Guatemala, Honduras and El Salvador, the three countries with the greatest food insecurity challenges as a result of coffee rust in Central America. According to the information provided by this organisation, emergency food assistance was supplied to more than 45000 families, which was, however, only a third of the families with severe or moderate food insecurity in 2013. Another activity with immediate impact was the release of tools and methods for training, which were implemented at national level, and of messages to be conveyed to farmers on best control techniques.

At the national level, one of the first measures was to try to avoid a second epidemic in 2013, by applying fungicides to control the disease. A second shock of the same magnitude as in 2012 would have further deteriorated the productive output and social situation of those affected, which had already been seriously impacted. Although pesticides are known to be detrimental to the natural enemies of coffee rust, such as the fungus Lecanicillium lecanii (Staver et al. 2001), these extreme actions were driven by the seriousness of the emergency, indicating that coffee rust management possibly needs to be rethought especially under the threat of progressive climate change (Vandermeer et al. 2014). A state of emergency was declared in Costa Rica, Honduras and Guatemala, which allowed the Costa Rican coffee sector to access national funds to fight the disease: MAG (Ministerio de Agricultura y Ganadería) and ICAFE donated fungicides to smallholders worth USD 3.7 million. In Honduras, IHCAFE (Instituto Hondureño del Café) used its trust fund to provide credits to farmers for purchasing fungicides. In Guatemala, ANACAFE negotiated fungicide prices with agrochemical companies to alleviate the financial burden on farmers in their attempts to control coffee rust. In addition, technical institutions intensively extended best practices to control coffee rust and to safely manage fungicides. 
The main problem faced by farmers was how to raise funds or soft loans in 2013, in the context of low coffee prices, for the renewal of the impacted coffee plantations, particularly the old susceptible plantations. Economic support for this activity is essential, particularly for smallholders. In Guatemala, a USD 100 million trust fund is being used for medium and large producers. However, there is not yet a mechanism for smallholders who are unable to access credit. On the contrary, Costa Rica has a USD 40 million trust fund specifically set up to support smallholders. More funds are necessary though. However, Central American countries, already heavily indebted, do not always intend to take new loans with international credit institutions for a crop which is no longer contributing significantly to the GDP.

\section{Solutions for the future}

\section{Coffee rust in the future}

The time of emergence of the climate change signal (the date at which the climate state moves out of its historical range of variability), in tropical areas, for mean annual temperature will possibly be reached within the current decade for Central America (Hawkins and Sutton 2012). Historical climate trends for Central America (1961-2003) have already shown an increase in maximum and minimum temperatures $\left(0.2-0.3{ }^{\circ} \mathrm{C} /\right.$ decade), and a decrease/increase in the frequency of cool/ warm days and nights respectively, combined with no trend in total annual rainfall but increased precipitation intensity (Aguilar et al. 2005). Other studies, also using station data but interpolated over forested areas, agree with these temperature trends and find a correlation between the temperature anomaly due to ENSO development and an increased spatial trend in these anomalies, spanning throughout Central America (Malhi and Wright 2004). Future climate scenarios show a drying trend over most of the region that is highly consistent across global climate models (Neelin et al. 2006) and emission scenarios, with precipitation anomalies showing less agreement in signal across models for southern countries (Panama and Costa Rica) (Imbach et al. 2012). The largest increase in temperature is expected between March and August (with a relatively large level of agreement across climate models) along with expected increases in the frequency of warm days and nights (in agreement with recent observed trends) (Biasutti et al. 2012). Precipitation reduction is also expected to be greatest between March and August and particularly between June and August (following a similar North-south uncertainty gradient as the annual anomaly) (Biasutti et al. 2012) resulting in a stronger and longer mid-summer drought under future climate scenarios for Central America (Rauscher et al. 2008). In Colombia, the situation with regard to rainfall is the opposite, and weather modelling indicates that the
Pacific Decadal Oscillation (PDO) is causing the start of a 30 years period where La Niña events, associated with rainier than normal conditions, will be more frequent (Laing and Evans 2011).

The weather conditions experienced in Central America in 2012 and Colombia in the period 2008-11 share some common characteristics with climate change forecasts. The severe coffee rust epidemics observed can therefore be considered as a warning for the future. In 2001, Chalfoun et al. (2001) had already noticed earlier development of coffee rust epidemics with respect to what was reported before. This was attributed to increased minimum temperatures during the winter. Ghini et al. (2011) showed a trend towards a reduction in the duration of the latency period of the disease in the future, and, hence, to an increase in epidemic intensity, due to increased temperatures. Coffee rust is not the only pest to fear. Coffee berry borer (H. hampei) will also increase as a threat to coffee (Jaramillo et al. 2011). There are therefore some warning signs that certain pests and diseases will highly impact the coffee crop as climate change progresses, especially if no appropriate actions are taken in the near future.

\section{Developing an early warning system}

The recent coffee rust epidemics experienced in Mesoamerica led to a renewed interest in the development of early warning systems, whose development was first undertaken in the 1980s in Latin America (Kushalappa et al. 1984; Kushalappa et al. 1986). An adequate system should be able to provide timely information to coffee farmers and authorities about the risk of coffee rust and propose appropriate actions to prevent productivity and social crises. Central America is already involved in this field. Risk indicators have been defined according to economic, phenological and meteorological factors that determined previous coffee rust epidemics (Table 1). Ways of monitoring these indicators and storing and processing the data, are under investigation. The profitability of the coffee crop is the economic indicator. It constitutes a proxy to determine the investments (in terms of inputs and labour) that farmers will make during the year. The expected yield of coffee is a strong phenological indicator. An increase in yield at regional, national or local levels implies an increase of the risk of a serious coffee rust epidemic occurring. In this regard, 2015 can already be considered risky for Central America, as most of the coffee plots severely impacted in 2012, and pruned in 2013 will have their first good harvest in 201516. Coffee profitability and expected yields are also very relevant in the forecasting of social crises. In addition, the ambition of this early warning system is to include weather indicators. Although much information is available on the relationships between weather and coffee rust prevalence, there is no recognized model able to predict the development of epidemics (Avelino and Savary 2002). This is an obstacle which 
needs to be overcome. Another difficulty is that coffee can be cultivated in a wide range of management systems where shade, in particular, can vary considerably (Toledo and Moguel 2012). Microclimates in these systems vary widely. Air and leaf temperatures are reduced by shade (by around $6{ }^{\circ} \mathrm{C}$ compared with full sun in certain cases) whereas relative humidity and leaf wetness are increased (Barradas and Fanjul 1986; Siles et al. 2010; Lopez-Bravo et al. 2012). In a specific climatic area, very different behaviours of coffee rust at the plot scale are therefore expected. Given such complexity, a model able to predict only large variation in coffee rust severity, valid in most of the systems, could be considered as being a first good step. For instance, the start of the rainy season is key for farmers in deciding on the implementation of chemical controls, independently of the shade system they have.

The Central American early warning system was conceived as a regional system. It is interesting to note that Colombian epidemics, which occurred between 2008 and 2011, did not act as a warning for Central American countries. Similarly, Central American epidemics, which occurred in 2012, were not considered as a warning in Peru and Ecuador which had severe epidemics in 2013. However, these epidemics were possibly related to each other. There are, therefore, benefits in integrating the assessments of epidemic risks in neighbouring regions, countries, and areas within the early warning system. However, an effort to harmonize methods and vocabulary used is necessary to interchange information between regions and countries that is comprehensible and therefore effective.

In addition, surveillance operations have been launched in Central America, particularly in Costa Rica, Guatemala and Honduras, where several hundreds of commercial plots are under observation. These operations are necessary to detect severe epidemics, which were not previously avoided despite warnings, and to take measures to fight them and their social consequences.

In this regard, the FAO (Food and Agriculture Organization of the United Nations) and PROMECAFE have started to take advantage of the new technologies, which provide sources of real-time temperature and humidity data, along with incidence measurements. These can be uploaded via an application on smartphones, which feed a model that can make probability maps available to users in real-time (http://satcafe.siatma. org/).

Coffee breeding for durable rust resistance

Breeding for coffee rust resistance is the best long-term solution for management of the disease. The discovery of the "Hibrido de Timor" (HDT) was a key breakthrough for the development of coffee breeding programs. HDT is an intraspecific hybrid between $C$. canephora and C. arabica. It possesses the complete resistance factors proceeding from
C. canephora, and has the same number of chromosomes as C. arabica, making crosses with this species possible. Before experiencing the disease, coffee-producing countries relied on the aid of CIFC, in Portugal, to develop resistant varieties based on HDT (Silva et al. 2006). Several countries through their national research centres have cooperated with CIFC for the development of local adapted coffee cultivars displaying rust resistance (Bettencourt 1981, 1983; Rodrigues Jr et al. 2000). After selection for several years, the local cultivars received regional names such as Oeiras, Tupi, Obata, Iapar59 (Brazil), Catrenic (Nicaragua), Costa Rica 95 (Costa Rica), Ihcafe 90 and Lempira (Honduras), Catisic (El Salvador), Mida 96 (Panama), Colombia variety (Rodrigues Jr et al. 2000) and more recently Castillo in Colombia. Some cultivars however have lost resistance, confirming that coffee rust can evolve (Rodrigues Jr et al. 2000). It is believed that the Colombia variety that lost complete resistance to rust several years ago, has kept partial resistance (Alvarado 2005), which, given its broad-spectrum nature, is less likely to promote the emergence of pathogen genotypes that overcome it (McDonald and Linde 2002; King et al. 2010). Partial resistance to coffee rust has been studied to a certain degree, but its deployment in commercial cultivars is still just a prospect.

Breakdowns of resistance have had the consequence of forcing breeders to develop new cultivars with durable resistance to the disease. One procedure is the pyramiding or the accumulation of several major resistance genes in a single cultivar. It is more difficult for the pathogen to overcome multiple resistance genes as it requires the loss or masking of its complementary avirulence genes. This approach has been used against coffee rust by introgressing the $\mathrm{S}_{\mathrm{H}} 3$ resistance gene from the species $C$. liberica, from which it originates, into $C$. arabica cultivars that already harboured other resistance genes (Santa Ram 2001). The strategy is particularly useful against asexual pathogens as evolution of virulence by recombination is denied to them (McDonald and Linde 2002). H. vastatrix was believed to be asexual until a recent report of hidden sexual reproduction called cryptosexuality (Carvalho et al. 2011). This indicates that the coffee rust uredospore was able to harbour a process of meiosis, confirming a first unnoticed observation by Rajendren (1967). The other alternative is promoting disruptive selection by mixing coffee genotypes with different resistance genes (McDonald and Linde 2002). This strategy has been used in the Colombia variety, which is actually a multiline. However, as already mentioned, most of the lines of this variety became gradually susceptible to virulent biotypes of the fungus in around 20 years. A new approach is probably needed. One novel possibility would be a mixture of coffee plants having complete and partial resistance to control the disease (McDonald and Linde 2002). Use of the gene $\mathrm{S}_{\mathrm{H}} 3$ in breeding schemes would seem appropriate as, so far the resistance it confers has proved durable in Latin America. 
In all cases, breeders have to consider the possible emergence of new coffee rust races, as shown by the appearance of the Ug99 strain of stem rust that can attack all cultivars of wheat grown in the world (Singh et al. 2006). The wheat stem rust (Puccinia graminis $f$. sp. tritici) is a pathogen that can cause up to $100 \%$ crop losses. Ug99 is a lineage of the fungus that is virulent against many resistance genes, which previously protected wheat against the rust (Singh et al. 2011). It is not difficult to envisage that a similar scenario might also take place with coffee rust, which is also developing new races that overcome coffee resistance genes deployed in commercial varieties (Alvarado-Alvarado and Moreno-Ruiz 2005; Cabral et al. 2009). A program similar to the Borlaug Global Rust Initiative (BGRI) devised for the monitoring of stem rust and the identification, characterization, selection and incorporation of genetic resistance into wheat genotypes (McIntosh and Pretorius 2011) might be implemented for coffee rust given the similarities encountered in both plant-pathogen systems. The involvement of research centres, national governments and funding agencies from several countries is crucial for the foundation of such an initiative. Results of the BGRI initiative for the safeguard of wheat farmers against stem rust are already a reality with regular early warning systems being implemented throughout the world and with the development of new resistant varieties of wheat that have been released in several countries (Singh et al. 2011). We believe that there is a growing need and willingness to develop a Coffee Rust Initiative that can help reduce the vulnerability of coffee to the rust pathogen.

Developing ecological control of coffee rust

In response to the coffee rust crisis, all governments and the entire value chains immediately implemented short term actions, with a strong focus on chemical control, looking for a "silver bullet" to cure the disease. Short-term responses must obviously be complemented with long term actions to prevent rather than cure, particularly under progressive climate change. A systems approach to manage this disease, and other pests and diseases, which have no clear genetic solution, is probably needed (Lewis et al. 1997; McRoberts et al. 2003; Vandermeer et al. 2014). The goal should be to structure and manage coffee systems to maximize their preventive strengths, by enhancing multiple ecological control mechanisms (Avelino et al. 2011). Shade management is surely the basis of these systems. Agroforestry is often cited as an option for enhancing smallholders' capacity to adapt to climate risks (Lasco et al. 2014). However, shade encompasses a series of aspects to consider, such as shade cover, shade diversity and nature of the species, number of strata, and horizontal spatial distribution, whose effects all need to be clarified in order to develop new "Best Practices" or, better still, new "Best Systems" to cope with climate change and pest and disease threats.
Other developments are needed for the ecological control of coffee rust. These include biological control, which has proved to be a cost-effective solution for low-income farmers in other crop systems (Neuenschwander 2004) and development of natural fungicides derived from plants or microorganisms for the management of the disease. In any case, whichever technical solution is implemented for the control of coffee rust, it will need the participation of experienced farmers, farmers' associations and extension services working in conjunction for the measures to be effective (Beed 2014).

\section{Socioeconomic solutions}

A crucial aspect that has been developed during the Central American coffee rust crisis, and that will serve well in the future, has been the strengthening of linkages between the actors involved in the supply and marketing chain, national and international technical and research organisations, and funding agencies. All these partners have key roles to play in strengthening rural communities and improving smallholder livelihoods. It is, however necessary to go further by strengthening ties among producers, favouring the emergence of organisations that will make them better able to deal with the challenges of tomorrow and to adopt new technologies. The low levels of technology adoption at field scale indicate that the methodologies of technology development and the technical advice provided to farmers need to be reconsidered. Actions are also needed at government scale, in the regulatory, financial and fiscal aspects, enabling the development of the production areas and the capitalisation of small coffee producers. Although coffee is losing importance in the region in macroeconomic terms, it still has a major social value.

\section{Conclusions}

The coffee rust crises suffered in Mesoamerica can be considered as a test in the face of global changes to come. A number of weaknesses have been detected in areas such as research, technology innovation and training, especially in Central America. The socioeconomic fragility of the coffee sector has also been highlighted. The coffee rust crises therefore act as a warning to Mesoamerica, and, at the same time, provide an opportunity to correct these weaknesses. Since coffee rust was first introduced to the region, the reaction has been to unite in the face of adversity and to launch ambitious programs of research and development.

Developing resistant cultivars is probably the best longterm strategy to control the disease. A worldwide Coffee Rust Initiative conceived with the goal of developing resistant cultivars to the disease should be implemented for coffee. However, coffee rust has shown a high capacity to evolve and overcome resistance genes in the plant. Therefore smart breeding programmes, including the use of partial resistance and 
effective resistance provided by major genes should be a priority. Coffee is not only exposed to coffee rust but also other pests and diseases, which could become serious threats in the future, particularly with the progression of climate change, such as the coffee berry borer for which no resistance is available. Breeding therefore needs to be part of a systems based strategy that enhances coffee's resilience to perturbations and exhibits natural strengths against future risks (Savary et al. 2011; Savary 2014).

Acknowledgments We thank the Cascade project (Ecosystem-based adaptation for smallholder farmers in Central America) for their financial support for the analysis of weather and climatic data at Central American scale. This project is part of the International Climate Initiative (ICI). The German Federal Ministry for the Environment, Nature Conservation, Building and Nuclear Safety (BMUB) supports this initiative on the basis of a decision adopted by the German Bundestag. We also acknowledge the Neumann Foundation for its financial support for the analysis of the weather and coffee rust data in Guatemala and the CGIAR Research Program on Climate Change, Agriculture and Food Security (CCAFS) for its support of the analysis in Colombia. Special thanks to Dr Serge Savary for critically reading the manuscript.

Open Access This article is distributed under the terms of the Creative Commons Attribution License which permits any use, distribution, and reproduction in any medium, provided the original author(s) and the source are credited.

\section{References}

Aguilar, E., Peterson, T.C., Obando, P.R., Frutos, R., Retana, J.A., Solera, M., et al. (2005). Changes in precipitation and temperature extremes in Central America and northern South America, 1961-2003. Journal of Geophysical Research: Atmospheres, 110(D23107). doi:10.1029/2005JD006119.

Alvarado, G. A. (2005). Evolution of Hemileia vastatrix virulence in Colombia. In L. Zambolim, E. M. Zambolim, \& V. M. P. Várzea (Eds.), Durable resistance to coffee leaf rust (pp. 99-115). Viçosa, Minas Gerais, Brazil: Universidade Federal de Viçosa.

Alvarado-Alvarado, G., \& Moreno-Ruiz, L. G. (2005). Cambio de la virulencia de Hemileia vastatrix en progenies de caturra $\mathrm{x}$ híbrido de Timor. Cenicafé, 56(2), 110-126.

Alvarado-Alvarado, G., Cortina-Guerrero, H. A., \& Posada-Suárez, H. E. (2005). Castillo: nueva variedad de café con resistencia a la roya. Avance Técnico, 337, 1-8.

Amador, J. A., Alfaro, E. J., Calderón, B., Durán-Quesada, A. M., Hidalgo, H. G., \& Rivera, I. L. (2013). Regional climate Central America and the Caribbean in state of the climate in 2012. Bulletin of the American Meteorology Society, 94(8), S154-S156.

Avelino, J., \& Savary, S. (2002). Rational and optimized chemical control of coffee leaf rust (Hemileia vastatrix). In Plantations, recherche, développement: recherche et caféiculture (pp. 134-143). Montpellier, France: CIRAD.

Avelino, J., Muller, R. A., Cilas, C., \& Velasco Pascual, H. (1991). Development and behavior of coffee orange rust (Hemileia vastatrix Berk. and Br.) in plantations undergoing modernization, planted with dwarf varieties in South-East Mexico. Café Cacao Thé, 35(1), 21-37.

Avelino, J., Muller, R. A., Eskes, A., Santacreo, R., \& Holguin, F. (1999). La roya anaranjada del cafeto: mito y realidad. In B. Bertrand \& B. Rapidel (Eds.), Desafios de la caficultura en Centroamerica (pp. 194-241). San Jose: IICA.
Avelino, J., Willocquet, L., \& Savary, S. (2004). Effects of crop management patterns on coffee rust epidemics. Plant Pathology, 53(5), 541-547.

Avelino, J., Zelaya, H., Merlo, A., Pineda, A., Ordonez, M., \& Savary, S. (2006). The intensity of a coffee rust epidemic is dependent on production situations. Ecological Modelling, 197(3-4), 431-447.

Avelino, J., Ten Hoopen, G. M., \& DeClerck, F. A. J. (2011). Ecological mechanisms for pest and disease control in coffee and cacao agroecosystems of the neotropics. In B. Rapidel, F. A. J. DeClerck, J.-F. Le Coq, \& J. Beer (Eds.), Ecosystem services from agriculture and agroforestry measurement and payment (pp. 91117). London: Earthscan.

Barradas, V. L., \& Fanjul, L. (1986). Microclimatic characterization of shaded and open-grown coffee (Coffea arabica L.) plantations in Mexico. Agricultural and Forest Meteorology, 38(1-3), 101-112.

Becker, S., \& Kranz, J. (1977). Comparative studies on the dispersal of Hemileia vastatrix in Kenya. Zeitschrift fuer Pflanzenkrankheiten und Pflanzenschutz, 84(9), 526-539.

Beed, F. D. (2014). Managing the biological environment to promote and sustain crop productivity and quality. Food Security, 6(2), 169-186. doi:10.1007/s12571-014-0333-9. Article.

Bettencourt, A. J. (1981). Melhoramento genético do cafeeiro: transferência de factores de resistência à Hemileia vastatrix Berk. and Br. para as principais cultivares de Coffea arabica L. . Lisboa: Junta de investigações científicas do Ultramar/Centro de Investigação das Ferrugens do cafeeiro, Oeiras.

Bettencourt, A. J. (1983). Características agronômicas de seleções derivadas de cruzamentos entre Híbrido de Timor e as variedades Caturra, Villa Sarchi e Catuai. Paper presented at the Simposio sobre ferrugens do cafeeiro, Oeiras, Portugal, October 17-20, 1983.

Biasutti, M., Sobel, A., Camargo, S., \& Creyts, T. (2012). Projected changes in the physical climate of the Gulf Coast and Caribbean. Climatic Change, 112(3-4), 819-845.

Cabral, P. G. C., Zambolim, E. M., Zambolim, L., Lelis, T. P., Capucho, A. S., \& Caixeta, E. T. (2009). Identification of a new race of Hemileia vastatrix in Brazil. Australasian Plant Disease Notes, 4(1), 129-130.

Carvalho, C. R., Fernandes, R. C., Carvalho, G. M. A., Barreto, R. W., \& Evans, H. C. (2011). Cryptosexuality and the genetic diversity paradox in coffee rust, Hemileia vastatrix. PLoS ONE, 6(11), e26387.

Chalfoun, S. M., Carvalho, V. L. D., \& Pereira, M. C. (2001). Efeito de alterações climáticas sobre o progresso da ferrugem (Hemileia vastatrix Berk. \& Br.) do cafeeiro (Coffea arabica L.). Ciencia E Agrotecnologia, 25(5), 1248-1252.

Cressey, D. (2013). Coffee rust regains foothold. Researchers marshal technology in bid to thwart fungal outbreak in Central America. Nature, 493, 587.

Cristancho, M. A., Rozo, Y., Escobar, C., Rivillas, C. A., \& Gaitán, A. L. (2012). Outbreak of coffee leaf rust (Hemileia vastatrix) in Colombia. New Disease Reports, 25, 19. doi:10.5197/j.2044-0588. 2012.025.019.

de Carvalho, V. L., Chalfoun, S. M., de Castro, H. A., \& de Carvalho, V. D. (1996). Influence of yield on coffee tree leaves rust. Pesquisa Agropecuária Brasileira, 31(6), 401-405.

Federación Nacional de Cafeteros de Colombia (2013). Comportamiento de la Industria Cafetera Colombiana 2013: Federación Nacional de Cafeteros de Colombia.

FEWS NET, RUTA, \& PROMECAFE (2014). Coffee producer and laborer income to decline for a second consecutive year. Special Report Central America (pp. 7).

Funk, C. C., Peterson, P. J., Landsfeld, M. F., Pedreros, D. H., Verdin, J. P., Rowland, J. D., et al. (2014). A quasi-global precipitation time series for drought monitoring. U.S. Geological Survey Data Series, 832, 4. doi:10.3133/ds832.

Ghini, R., Hamada, E., Pedro Júnior, M. J., \& Gonçalves, R. R. V. (2011). Incubation period of Hemileia vastatrix in coffee plants in Brazil simulated under climate change. Summa Phytopathologica, 37(2), 85-93. 
Gil Fagioli, S. L., Berry, D., \& Bieysse, D. (1990). Research on incomplete resistance to Hemileia vastatrix Berk et $\mathrm{Br}$. In a group of genotypes of Coffea arabica L. From Ethiopia. Café Cacao Thé, 34(2), $105-144$.

Hawkins, E., \& Sutton, R. (2012). Time of emergence of climate signals. Geophysical Research Letters, 39(1), L01702.

ICO (2014). World coffee trade (1963 - 2013): A review of the markets, challenges and opportunities facing the sector. (pp. 27).

Imbach, P., Molina, L., Locatelli, B., Roupsard, O., Mahé, G., Neilson, R., et al. (2012). Modeling potential equilibrium states of vegetation and terrestrial water cycle of Mesoamerica under climate change scenarios. Journal of Hydrometeorology, 13(2), 665-680.

Jaramillo, J., Muchugu, E., Vega, F. E., Davis, A., Borgemeister, C., \& Chabi-Olaye, A. (2011). Some like It Hot: the influence and implications of climate change on coffee berry borer (hypothenemus hampei) and coffee production in east Africa. PLoS ONE, 6(9), e24528.

King, J. N., David, A., Noshad, D., \& Smith, J. (2010). A review of genetic approaches to the management of blister rust in white pines. Forest Pathology, 40(3-4), 292-313.

Kushalappa, A. C., Akutsu, M., Oseguera, S. H., Chaves, G. M., Melles, C. A., Miranda, J. M., et al. (1984). Equations for predicting the rate of coffee rust development based on net survival ratio for macrocyclic process of Hemileia vastatrix. Fitopatologia Brasileira, 9, 255271.

Kushalappa, A. C., Hernández, T. A., \& Lemos, H. G. (1986). Evaluation of simple and complex coffee rust forecasts to time fungicide application. Fitopatologia Brasileira, 11, 515-526.

Laing, A., \& Evans, J. L. (2011). Introduction to tropical meteorology. In Educational material from The COMET Program: University Corporation for Atmospheric Research.

Lasco, R. D., Delfino, R. J. P., \& Espaldon, M. L. O. (2014). Agroforestry systems: helping smallholders adapt to climate risks while mitigating climate change. WIREs Climate Change 2014. doi:10.1002/wcc. 301

Lewis, W. J., vanLenteren, J. C., Phatak, S. C., \& Tumlinson, J. H. (1997). A total system approach to sustainable pest management. Proceedings of the National Academy of Sciences of the United States of America, 94(23), 12243-12248.

Lopez-Bravo, D. F., Virginio-Filho, E. D. M., \& Avelino, J. (2012). Shade is conducive to coffee rust as compared to full sun exposure under standardized fruit load conditions. Crop Protection, 38, 21-29.

Malhi, Y., \& Wright, J. (2004). Spatial patterns and recent trends in the climate of tropical rainforest regions. Philosophical Transactions of the Royal Society B, 359(1443), 311-329.

Mayne, W. W. (1930). Seasonal periodicity of coffee leaf disease (Hemileia vastatrix B. \& Br.) (Vol. 4, Bulletin): Mysore Coffee Experimental Station.

McCook, S. (2009). La roya del Café en Costa Rica: epidemias, innovación y medio ambiente, 1950-1995. Revista de Historia, 59-60, 99-117.

McDonald, B. A., \& Linde, C. (2002). Pathogen population genetics, evolutionary potential, and durable resistance. Annual Review of Phytopathology, 40, 349-379.

McIntosh, R. A., \& Pretorius, Z. A. (2011). Borlaug global rust initiative provides momentum for wheat rust research. Euphytica, 179(1), 12.

McRoberts, N., Hughes, G., \& Savary, S. (2003). Integrated approaches to understanding and control of diseases and pests in field crops. Australasian Plant Pathology, 32(2), 167-180.

Muller, R. A. (1971). La rouille du caféier (Hemileia vastatrix) sur le continent américain. Café Cacao Thé, 15(1), 24-30.
Mundt, C. C., Sackett, K. E., Wallace, L. D., Cowger, C., \& Dudley, J. P. (2009). Long-distance dispersal and accelerating waves of disease: empirical relationships. American Naturalist, 173(4), 456-466.

Neelin, J. D., Munnich, M., Su, H., Meyerson, J. E., \& Holloway, C. E. (2006). Tropical drying trends in global warming models and observations. Proceedings of the National Academy of Sciences, 103, 6110-6115.

Neuenschwander, P. (2004). Harnessing nature in Africa - biological pest control can benefit the pocket, health and the environment. Nature, 432(7019), 801-802.

Phiri, N. A., Hillocks, R. J., \& Jeffries, P. (2001). Incidence and severity of coffee diseases in smallholder plantations in northern Malawi. Crop Protection, 20(4), 325-332.

Rajendren, R. B. (1967). A new type of nuclear life cycle in Hemileia vastatrix. Nature, 213(7), 105-106.

Rauscher, S., Giorgi, F., Diffenbaugh, N., \& Seth, A. (2008). Extension and intensification of the meso-American mid-summer drought in the twenty-first century. Climate Dynamics, 31(5), 551-571.

Rayner, R. W. (1961). Germination and penetration studies on coffee rust (Hemileia vastatrix B. \& Br.). Annals of Applied Biology, 49(3), 497-505.

Rivillas Osorio, C. A., Serna Giraldo, C. A., Cristancho Ardila, M. A., \& Gaitan Bustamante, A. L. (2011). La roya del cafeto en Colombia impacto, manejo y costos del control. Chinchiná, Caldas, Colombia: CENICAFE

Rodrigues Jr, C. J., Várzea, V. M. P., Silva, M. C., Guerra-Guimarães, L., Rocheta, M., \& Marques, D. V. (2000). Recent advances on coffee leaf rust. Paper presented at the International Scientific Symposium on Coffee, Bangalore December 4, 2000.

Rozo, Y., Escobar, C., Gaitán, Á., \& Cristancho, M. (2012). Aggressiveness and genetic diversity of Hemileia vastatrix during an epidemic in Colombia. Journal of Phytopathology, 160(11-12), 732-740.

Ruiz García, A., \& Mendoza Tijerino, F. (2014). Impacto de la roya en los medios de vida de familias productoras y journaleros del café en Nicaragua, 2nd Edition. (pp. 72): Nitlapan, Oxfam, Echo.

Santa Ram, A. (2001). Breeding for rust resistance in coffee: the gene pyramid model. Journal of Plantation Crops, 29, 10-15.

Savary, S. (2014). The root of crop health: cropping practices and disease management. Food Security, In print.

Savary, S., Ficke, A., Aubertot, J.-N., \& Hollier, C. (2011). Crop production and food security: impact of global change on shifting agricultural systems. In B. Freedman (Ed.), (Vol. Global Environmental Change, Handbook of Global Environmental Pollution): Springer Reference.

Schuppener, H., Harr, J., Sequeira, F., \& González, A. (1977). First occurence of the coffee leaf rust Hemileia vastatrix in Nicaragua, 1976, and its control. Café Cacao Thé, 21(3), 197-202.

Segovia, A. (2004). Centroamérica después del café: el fin del modelo agroexportador tradicional y el surgimiento de un nuevo modelo. Revista Centroamericana de Ciencias Sociales, 1(2), 5-38.

Sera, G. H., Sera, T., Ito, D. S., Azevedo, J. A. D., Mata, J. S. D., Doi, D. S., et al. (2007). Resistance to leaf rust in coffee carrying SH3 gene and others SH genes. Brazilian Archives of Biology and Technology, 50(5), 753-757.

Siles, P., Harmand, J. M., \& Vaast, P. (2010). Effects of Inga densiflora on the microclimate of coffee (Coffea arabica L.) and overall biomass under optimal growing conditions in Costa Rica. Agroforestry Systems, 78(3), 269-286.

Silva, M. D. C., Varzea, V., Guerra-Guimaraes, L., Azinheira, H. G., Fernandez, D., Petitot, A. S., et al. (2006). Coffee resistance to the main diseases: leaf rust and coffee berry disease. Brazilian Journal of Plant Physiology, 18(1), 119-147. 
Singh, R. P., Hodson, D. P., Jin, Y., Huerta-Espino, J., Kinyua, M. G., Wanyera, R., et al. (2006). Current status, likely migration and strategies to mitigate the threat to wheat production from race Ug99 (TTKS) of stem rust pathogen. CAB Reviews: Perspectives in Agriculture, Veterinary Science, Nutrition and Natural Resources, 1(54), doi:10.1079/PAVSNNR20061054.

Singh, R. P., Hodson, D. P., Huerta-Espino, J., Jin, Y., Bhavani, S., Njau, P., et al. (2011). The emergence of Ug99 races of the stem rust fungus is a threat to world wheat production. Annual Review of Phytopathology, 49, 465-481.

Staver, C., Guharay, F., Monterroso, D., \& Muschler, R. G. (2001). Designing pest-suppressive multistrata perennial crop systems: shadegrown coffee in central America. Agroforestry Systems, 53, 151-170.

Taugourdeau, S., le Maire, G., Avelino, J., Jones, J. R., Ramirez, L. G., Jara Quesada, M., et al. (2014). Leaf area index as an indicator of ecosystem services and management practices: an application for coffee agroforestry. Agriculture, Ecosystems \& Environment, 192, 19-37.

Toledo, V. M., \& Moguel, P. (2012). Coffee and sustainability: the multiple values of traditional shaded coffee. Journal of Sustainable Agriculture, 36(3), 353-377.

Van der Vossen, H. A. M. (2009). The cup quality of disease-resistant cultivars of Arabica coffee (Coffea arabica). Experimental Agriculture, 45(3), 323-332.

Vandermeer, J., Jackson, D., \& Perfecto, I. (2014). Qualitative dynamics of the coffee rust epidemic: educating intuition with theoretical ecology. BioScience. doi:10.1093/biosci/bit034.

Vicegerencia Técnica de UNICAFE. (1996). Informe sobre daño causado por la roya a las plantaciones de café. (pp. 4). Managua: Unión Nicaraguense de Cafetaleros.

Waller, J. M. (1972). Coffee rust in Latin America. PANS, 18(4), 402-408.

Waller, J. M. (1982). Coffee rust-epidemiology and control. Crop Protection, 1(4), 385-404.

Wellman, F. L. (1952). Peligro de introducción de la Hemileia del café a las Américas. Turrialba, 2(2), 47-50.

Zambolim, L., Silva-Acuña, R., Do Vale, F. X. R., \& Chaves, G. M. (1992). Influencia da produção do cafeeiro sobre o desenvolvimento da ferrugem (Hemileia vastatrix). Fitopatologia Brasileira, 17, 32-35.

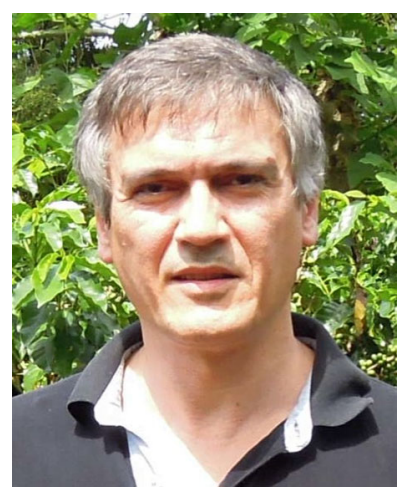

Jacques Avelino holds a $\mathrm{PhD}$ in plant pathology from the University of Orsay, Paris XI, France. His $\mathrm{PhD}$ thesis research was carried out in Honduras between 1994 and 1997 on the epidemiology of coffee rust under Dr. Serge Savary. He works for CIRAD (Centre International en Recherche Agronomique pour le Développement, France). He is currently posted at IICA (InterAmerican Institute for Cooperation on Agriculture), within the PROMECAFE network, and has been based at CATIE (Centro Agronómico Tropical de Investigación y Enseñanza, Costa Rica) since 2007. He has 28 years of experience researching coffee pests and diseases, in particular coffee rust, and 7 years of experience related to cocoa. He also has 10 years of experience in the area of coffee quality. During his career, he has established research and development operations in Mexico, Guatemala, Honduras, Nicaragua, Costa Rica, Venezuela, Indonesia, Laos, and Papua New Guinea.

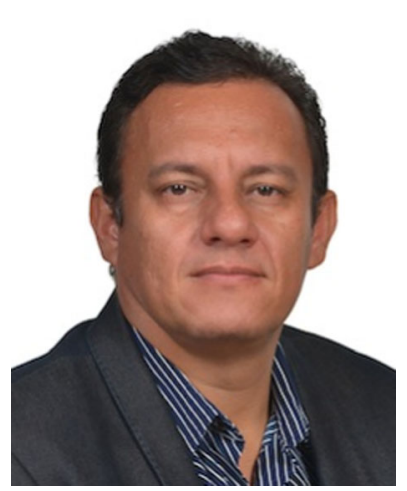

Marco Cristancho is currently a Principal Investigator at the National Colombian Center for Coffee Research-CENICAFE. He has led numerous grant applications supported by NSF, Latin American and international science sponsor agencies. Marco received his Ph.D (Molecular Biology of Higher Plants) from The University of Manchester in the U.K. and his B.Sc. (in Microbiology) from Universidad de los Andes in Colombia. He also completed two Post-Doctoral research assignments at Cornell University. He has more than 20 years of experience working on plant pathogen interactions and plant pathogen management strategies and epidemiology. Additionally, Marco has over 10 years expertise working on genomics and bioinformatics projects. He has been a consultant to Central American countries for rust management strategies and has ongoing collaborative research projects with fellow scientists at Cornell University, the University of Maryland, Arizona State University, and IRD-CIRAD in France related to Coffee Genomics and bioinformatics. He is part of several international consortia currently sequencing and analyzing the coffee plant, fungi and insect genomes.

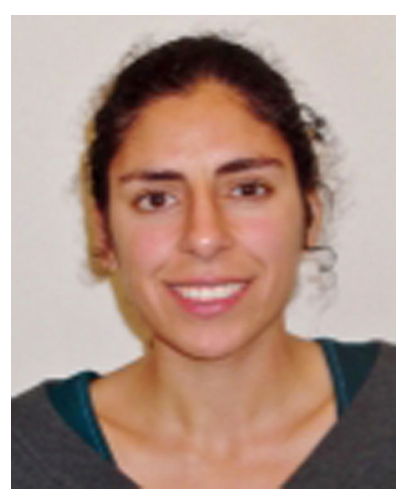

Selena Georgiou currently works at CATIE in Costa Rica. Her work is focussed on analysing the weather and climate conditions related to the 2012 epidemic of coffee rust disease in Guatemala. She is also working on a project to construct models of the impacts of climate change on ecosystems in Central America through the use of a dynamic vegetation model forced with meteorological data. She previously worked as a research scientist on projects related to improving rainfall estimation using weather radar data at the Met Office based in Exeter, UK. Prior to this she obtained a masters degree in remote sensing and image processing at Edinburgh University. Her dissertation was based on determining the depth of supra-glacial lakes in Greenland by their remotely sensed reflectance. As an undergraduate, she studied Computational Physics at Heriot Watt University, Edinburgh. She has worked previously as an assistant teacher at schools in Italy and Japan, and on environmental and community projects in Borneo. She takes a keen interest in issues related to the environment and sustainability. Her main interests are in meteorology related to agriculture, remote sensing, weather forecasting and climate change impacts. 


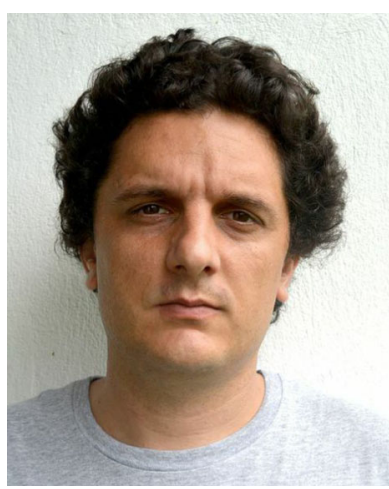

change assessments.
Pablo Imbach has over 15 years of experience working in Latin America and is currently affiliated to CATIE's Climate Change \& Watersheds Program. During the last 6 years his focus has been on researching the biophysical aspects of climate change, biodiversity conservation and ecosystem services. He has made extensive use of modeling tools at different geographical scales for land use change, hydrology, ecosystem dynamics, atmospheric monitoring, species modeling and climate

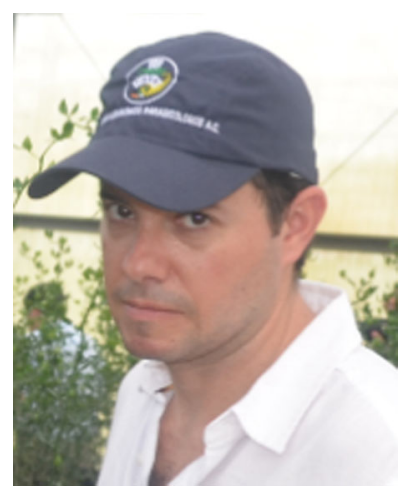

Gustavo Bornemann studied agriculture engineering at the University of Santa Maria, Brazil and has an MBA in Environmental Management. He also has a Masters in Environmental Science from the University of Granada, Spain. He is currently working as an International consultant for FAO's Subregional Office for Mesoamerica on a coffee leaf rust subregional project. He is interested in the use of new technologies to support agriculture producers with phytosanitary issues, including the use of app developments or unmanned aerial vehicles (UAVs). He has a particular interest in the application of these technologies at field level to deal with food security and sustainability issues under climate change scenarios.

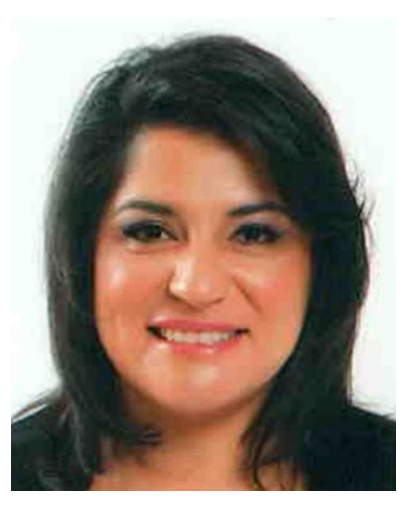

Lorena Aguilar is a Technical Representative with the Food Security Early Warning System Network (FEWS NET) for the Central American and Caribbean region. She holds a B.Sc. in Computer Engineering, an M.Sc. in Reliability of Information Systems, an M.Sc. in Geographical Information Systems and a postgraduate qualification in Food Security. She has spent nearly 20 years working on development projects with international organisations and government agencies

based throughout Central America. Her work experience has included working with a German Cooperation for 4 years, the Guatemalan government, and the United Nations for 2 years. She has also worked in consultancy positions with a Spanish cooperation and for the United States Geological Service (USGS), where she provided regional assistance related to reconstruction following Hurricane Mitch (2001 to 2003), followed by working as a regional scientist for the FEWS NET program (2004 to 2008), where she was responsible for monitoring the climate and the production of basic grains in the region. She continued to work within FEWS NET as the National Representative for Guatemala (2008 to 2009), and since then as a Regional Representative. Within her current position, she has had the opportunity to monitor the socioeconomic situation and impacts of various events that have affected the livelihoods of the poorest people in the region, and led to food insecurity. Lorena Aguilar loves her work, especially as it gives her the opportunity to contribute to capacity development within the Central American region. Under her direction, improvements have been made to the monitoring systems managed by the Guatemalan government, including the Crop and Price Monitoring System and the development of a database to recover rainfall data.

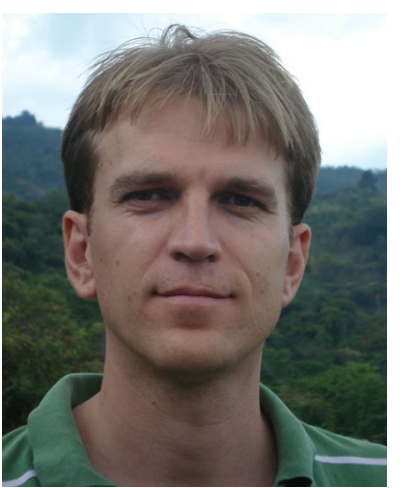

Peter Läderach holds an M.Sc in Geography and a Ph.D. in Tropical Agriculture. Since 2005 he has led a team at the International Centre for Tropical Agriculture (CIAT) that has developed and implemented spatial analyses and supply chain tools for coffee and cocoa that allow: the spatial identification and prediction of product attributes; the control and management of product quality; the information flow along the supply chain; and the quantification of the impact of climate change. Peter and his team are currently implementing several projects in Latin America and Africa that deploy these methodologies for a variety of crops.

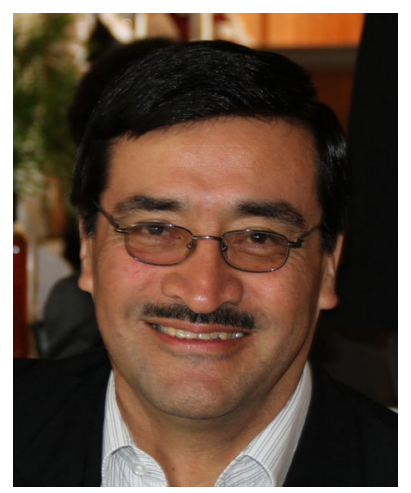

Francisco Anzueto holds a B.Sc in Agronomy, an M.Sc. in Biology and Agronomy, and obtained a $\mathrm{PhD}$ in Coffee Plant Breeding in France in 1993. Since 1986 he has worked as Director of the Research Centre of the "Asociación Nacional del Café de Guatemala". $\mathrm{He}$ conducts research in the areas of: plant breeding; nematology; food quality and safety; and the coffee environment and has experience providing technical advice to farmers about coffee production systems. He has been comanager of several regional research programs in Central America. 


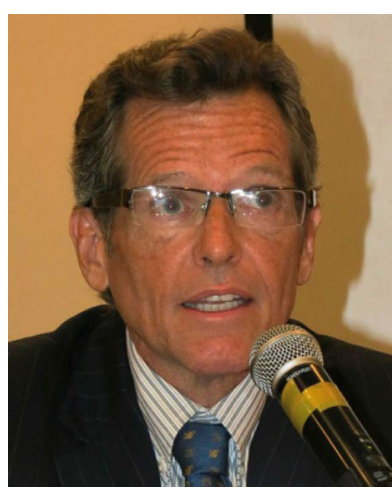

Allan Hruska is Plant Production and Protection Officer of the Food and Agriculture Organization of the United Nations (FAO), based in the Sub-regional Office for Mesoamerica in Panama since 2008. Previously he was based in the Regional Office for Latin America and the Caribbean, in Santiago, Chile. Dr. Hruska has more than 25 years of experience in crop production and protection, including seed systems, conservation agriculture, pesticide management, early warning systems for emerging plant pests and diseases, including policies, programmes and international agreements that support their implementation. He has lived and worked in Panama, Chile, Nicaragua, Honduras and Costa Rica. Before his career with FAO he occupied high level positions with CARE, Zamorano and Nicasalud. He has been a professor at the National Agrarian University in Nicaragua and Zamorano in Honduras. He earned a PhD in entomology from North Carolina State University under Dr. Fred Gould, an MSc in genetics from Duke University and a BS from the University of Michigan.

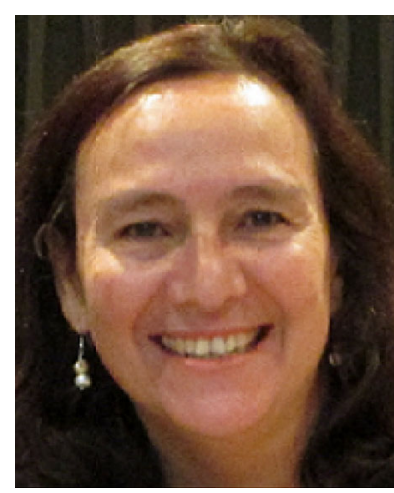

Carmen Morales is an Agronomy Engineer and holds a Ph.D. in Agrarian Economy from Universidad Politécnica de Madrid. Her Ph.D. thesis research was carried out in Mexico on the incorporation of a coffee farmers' organization into the world market through fair trade, organic and specialty coffee niches. She assisted PROMECAFE with coordinating the Action Plan 2013 to combat coffee rust in Central America and the Dominican Republic. She has participated in food security assessments and rural development projects in Latin America and Africa for 20 years. 